\author{
UNIVERSIDADE DE SÃO PAULO \\ FACULDADE DE ODONTOLOGIA DE BAURU
}

FERNANDA ARAUJO SAMPAIO

Somatosensory, inflammatory and pain evaluation during Orthodontic Treatment

Avaliação das alterações dolorosas, inflamatórias e somatossensoriais em pacientes durante tratamento ortodôntico 

FERNANDA ARAUJO SAMPAIO

Somatosensory, inflammatory and pain evaluation during Orthodontic Treatment

Avaliação das alterações dolorosas, inflamatórias e somatossensoriais em pacientes durante tratamento ortodôntico

Tese constituída por artigos apresentada a Faculdade de Odontologia de Bauru da Universidade de São Paulo para obtenção do título de Doutor em Ciências no programa de Ciências Odontológicas Aplicadas, área de concentração Reabilitação Oral.

Orientador: Prof. Dr. Paulo César Rodrigues Conti 


\section{Sampaio, Fernanda}

Sa47s Somatosensory, inflammatory and pain evaluation during Orthodontic Treatment/ Fernanda Araujo Sampaio. - Bauru, 2017.

76 p. : il. ; $31 \mathrm{~cm}$.

Tese (Doutorado) - Faculdade de Odontologia de Bauru. Universidade de São Paulo

Orientador: Prof. Dr. Paulo César Rodrigues Conti

Autorizo, exclusivamente para fins acadêmicos e científicos, a reprodução total ou parcial desta dissertação/tese, por processos fotocopiadores e outros meios eletrônicos.

Assinatura:

Data:

Comitê de Ética da FOB-USP

Protocolo $\mathrm{n}^{\circ}$ : CAAE

37635614.8.0000.5417

Data: 15/05/2015 
FOLHA DE APROVAÇÃO 



\section{DEDICATÓRIA}

Dedico este trabalho aos meus pais, Fernando e Claudine, que nunca mediram esforços para que eu conquistasse os meus objetivos. Por me permitirem sonhar. Por sonharem comigo. Não saberia expressar em palavras a gratidão que sinto. Amo vocês infinitamente. 



\section{AGRADECIMENTOS}

Agradeço em especial ao meu orientador, Prof. Dr. Paulo Cesar Rodrigues Contí, o senhor fez com que eu me apaixonasse ainda mais por essa área tão difícil, e ao mesmo tempo tão gratificante, que é a Dor Orofacial. Lhe admiro como professor, como orientador, e mais ainda como pessoa. Obrigada por servir de exemplo a todos nos que Ihe acompanhamos do Bauru Orofacial Pain Group. É uma honra fazer parte desse time. 

A Deus, por ser o responsável por tudo. Por estar ao meu lado em todos os momentos dessa caminhada. Por ter me dado força para continuar, mesmo quando pensei em desistir.

Ao meu esposo, Phillipe, que esteve comigo durante toda essa caminhada. Que foi meu apoio, meu abrigo, minha válvula de escape em tantos momentos. Obrigada por me entender, por dividir comigo os seus sonhos e me deixar fazer parte deles. Te amo

As minhas irmãs, Maína e Paloma, por todo o apoio que sempre me deran. Por terem me ensinado a dividir, a perdoar, a ser família. Sisters, amo vocês e quero vocês sempre pertinho de mim. Meu agradecimento se estende também aos meus cunhados João Breno e Gabrielpor serem como irmãos. E, não menos importante, ao meu sobrinho querido, Bernardo, por ser a alegria de toda a família. Zoquinho você é o nosso maior elo de amor.

Aos meus avós, José Valmir e Norma (in memoriam) e José María (ín memoriam) e Celína, porque sei que amor de avós é maior do que tudo. Minha admiração eterna a vocês.

Aos meus co-orientadores. Dr. Elíav, Profa Dra Daniella Garí, Prof. Dr. Gustavo Garlet, por me ensinarem a cada dia como ser um profissional integro, de uma competência impar. Agradeço por cada orientação e cuidado com nossa pesquisa. Seus ensinamentos foram muito valiosos para mim

A minha grande amiga, irmã Carol. Não tenho palavras para agradecer tudo que você é para mim. Você foi minha única família em Nova lorque, Foi os cuidados da minha mãe, os abraços do meu pai, a risada das minhas irmãs.

Uma extensão da minha família. Obrigada por todo o carinho e cuidado comigo. 

Aos amigos que Bauru me trouxe, aproximou e re-aproximou. Marí, Jojo e Celínho vocês fizeram toda diferença em minha vida em Bauru. Como agradecer a vocês por todos os momentos que vivemos, por tantas conversas, e bote conversa nisso, Por serem família. Leo e Sol, que sempre me acolheram com muito carinho. Muito bom ter dividido tantos momentos com vocês. Leo você é a pessoa com o coração "mais baum" (como você diz) que existe. Não perca essa sua generosidade nunca.

Te admiro demais.

Aos amigos do Bauru Orofacial Paín Group (Prof Dr. Conti, Prof Dr. Leonardo, Yuri, Carol, André, Naila, Julyanna, Dyna, Laila, Leticia e todos que por aqui passaram). É uma honra participar desse grupo. Fico feliz em dividir com vocês o amor pela DTM e Dor Orofacial

Aos meu amigos da Rutgers University, Richa, Tina, Hamad, Abdulwaha6, Moín, Nírupama, Deepika e Khaled, sem palavras para agradecer esses dois anos de mestrado juntos. Por terem a maior paciência com a amiga brasileira com costumes tão diferentes que vocês acolheram. Me entenderam. Me ensinaram. Eu aprendi com vocês que somos todos irmão, que nossas culturas não determinam caráter, que a minha liberdade termina quando começa a de vocês. Vocês só me trouxeram alegria nesses dois anos de aprendizado diário.

Aos meus professores do Departament of Diagnostic Science - Rutgers Dental School, onde fiz meu mestrado. Vocês me fizeram apaixonar por essa área, minha admiração e carinho por cada um. Em especial ao Dr. Markman por me receber sempre com um sorriso, suas palavras de incentivo fizeram a diferença. Você acreditou em mim antes mesmo que eu pudesse acreditar. Ao $\mathcal{D}$. Heir por ser o americano mais brasileiro que conheço, por ser a maior referência de diagnóstico em Dor Orofacial, aprendi com você que todo paciente realmente te uma história para contar. A querida Cíbele, por ser um doce de pessoal no meio de todo o caos. Olhar 

para você me transmitia paz, me fazia voltar para casa. Você foi Deus se fazendo presente em minha vida. Palavras não saberiam expressar meu carinho e gratidão por você.

\section{À Faculdade de Odontología de Bauru, Universidade de}

São Paulo, através da pessoa Profa. Dra. Maria Aparecida Moreira Machado, diretora, e do Prof. Dr. Carlos Ferreira dos Santos, vice-diretor, pelo apoio sempre e por essa oportunidade de conquista nesta casa.

Aos funcíonáríos da $\mathcal{F O B}$, que não mediram esforços para facilitar nosso dia a dia. Em espacial a Deborah e a Cleo que sempre se prontificaram a me ajudar como um sorriso no rosto.

Aos pacíentes que se prontificaram a participar desta pesquisa minha eterna gratidão.

Aos alunos de especíalização e mestrado do Departamento de Ortodontia que sempre estavam dispostos a me ajudar a capacitar pacientes. Sem vocês não teria conseguido. Muito obrigada.

A Fundação de Amparo à Pesquísa do estado de São Paulo, processo $n^{\circ}$ 2014/18741-0 e a Coordenaçáo de Aperfeiçoamento de Pessoal de Nível Superior pelo apoio financeiro dado para execução deste trabalho. 

"O sucesso nasce do querer, da determinação e persistência em se chegar a um objetivo. Mesmo não atingindo o alvo, quem busca e vence obstáculos, no mínimo fará coisas admiráveis.

José de Alencar 



\section{ABSTRACT \\ Somatosensory, inflammatory and pain evaluation during Orthodontic Treatment}

Experimental tooth movement has been shown to induce inflammation and release of chemical mediators. Inflammation can also alter nerve function that can be measured with Quantitative Sensory Testing (QST). Various authors have studied orthodontic pain and the different factors that modify it. But, to our knowledge none studied a possible individual endogenous analgesia effect on orthodontic induced-pain. The aim of the present study was to investigate the impact of orthodontic separator and short-term fixed orthodontic appliance on the somatosensory function and gingival cervicular fluid (GCF) levels of IL-1 $\beta$, IL-8, IL-6 and TNF- $\alpha$. Thirty patients were evaluated as follow: baseline, 24h-after elastomeric separator (24h-aES), $24 \mathrm{~h}$ and 1 month after bonding the fixed appliance (aBFA) at maxillary and mandibular arch. The outcome variables were: self-reported pain, QSTs (current perception threshold, cold detection threshold, warm detection threshold, mechanical detection threshold, mechanical supra threshold and wind-up ratio, CPM and sample from the GCF in order to assess cytokines profile (IL-1 $\beta$, IL-8, IL-6 and TNF- $\alpha$ ). ANOVA and Tukey's post hoc analyses were performed $(\mathrm{a}=5 \%)$. The participants were divided in two groups: $\mathrm{G} 1)$ RESPONDERS (more than 10\% decrease in WUR); G2) NON-RESPONDERS (not show more than $10 \%$ decrease in WUR). T-test for independent sample was performed. A Bonferroni correction lowered the significance level to $0.1 \%(p=0.001)$ as the cut-off point to establish the statistical significance for the mean difference between CPM responders and non-responders. Patients were less sensitive to pin prick pain $(\mathrm{MST})$ at $24 \mathrm{~h}(\mathrm{p}<0.020)$ and 1month-aBFA $(p<0.002)$ when compared to baseline. Significant increases in IL-6 levels were observed 24h-aBFA $(\mathrm{p}<0.023)$ and in IL-1 $\beta(\mathrm{p}<0.001)$ and TNF- $\alpha(\mathrm{p}<0.026)$ levels at 1 month-aBFA when compared to baseline values $(p<0.023)$. There was no significant difference in somatosensory function, pain report and GCF cytokines when compared between G1 and G2. In conclusion, orthodontic-induced inflammation may have a modality specific effect on somatosensory function of the trigeminal system. In addition, elastic separators seem not an ideal model to study possible inflammatory changes following orthodontic tooth movement. Moreover, CPM efficiency may not significantly influence somatosensory function, pain intensity or released of inflammatory cytokines following 

orthodontic tooth movement up to 1 month. However, remained to be confirmed and further investigations are required in intraoral somatosensory assessment.

KEYWORDS: Orthodontic Appliances; Pain; Cytokines; Quantitative Sensory Testing; Gingival Crevicular Fluid, Conditioned Pain Modulation 



\section{RESUMO}

\section{Avaliação das alterações dolorosas, inflamatórias e somatossensoriais em pacientes durante tratamento ortodôntico: um estudo controlado}

O movimento dentário experimental demonstrou induzir inflamação e liberação de mediadores químicos. A inflamação também pode alterar a função nervosa que pode ser medida através de testes quantitativos sensoriais (QST). Vários autores estudaram a dor ortodôntica e os diferentes fatores que a modificam. Mas, ao nosso conhecimento, não há estudos avaliando o efeito da analgesia endógena individual na dor induzida por ortodontia. $\mathrm{O}$ objetivo do presente estudo foi investigar o impacto do separador ortodôntico e do aparelho ortodôntico fixo de curta duração na função somatossensorial e nos níveis do fluido cervical gengival (GCF) de IL-1 $\beta$, IL-8, IL-6 e TNF- $\alpha$. Trinta pacientes foram avaliados da seguinte forma: valores basais, 24 horas após separador elástico (24h- AES), 24h e 1 mês após a ligação do aparelho fixo (aBFA) no arco maxilar e mandibular. As variáveis avaliadas foram: dor, QSTs (limiar de percepção elétrica, limiar de detecção ao frio, limiar de detecção ao quente, limiar de detecção mecânica, supralimiar mecânico e razão de somação temporal, CPM e amostra do GCF para avaliar perfil das citocinas ( IL-1 $\beta$, IL-8, IL-6 e TNF- $\alpha$ ). A ANOVA e as análises post hoc de Tukey foram realizadas $(\mathrm{a}=5 \%)$. Os participantes foram divididos em dois grupos: G1) CPM-RESPONDENTES (diminuição de mais de $10 \%$ em WUR); G2) CPM-NÃO RESPONDENTES (não mostra mais de $10 \%$ de diminuição na WUR). Foi realizado teste T para amostra independente. Uma correção de Bonferroni reduziu o nível de significância para $0,1 \%(\mathrm{p}=0,001)$ como ponto de corte para estabelecer a significância estatística para a diferença média entre G1 o G2. Os pacientes eram menos sensíveis à dor de pin $(\mathrm{MST})$ às $24 \mathrm{~h}(\mathrm{p}<0,020)$ e 1 mês-aBFA $(\mathrm{p}<0,002)$ quando comparado à linha de base. Observaram-se aumentos significativos nos níveis de IL-6 níveis 24h-aBFA ( $p<0,023)$ e nos níveis de IL-1 $\beta$ ( $p<0,001)$ e TNF- $\alpha(p<0,026)$ em 1 mês-aBFA quando comparados aos valores basais $(\mathrm{p}<0,023)$. Não houve diferença significativa na função somatossensorial, no relatório da dor e citocinas do FCG quando comparadas entre G1 e G2. Em conclusão, a inflamação induzida por ortodontia pode ter um efeito de modalidade específico na função somatossensorial do sistema trigeminal. Além disso, os separadores elásticos não parecem ser um modelo ideal para estudar possíveis alterações inflamatórias após o movimento dentário ortodôntico. Além disso, a eficiência de CPM pode não 

influenciar significativamente a função somatossensorial, intensidade da dor ou liberação de citocinas inflamatórias após o movimento dentário ortodôntico até 1 mês. No entanto, outras investigações são necessárias na avaliação somatossensorial intraoral.

PALAVRAS-CHAVE: Aparelho Ortodôntico, Dor, Citocinas, Testes Quantitativos Sensoriais, Fluido Crevicular Gengival, Modulação de Dor 



\section{TABLE OF CONTENTS}

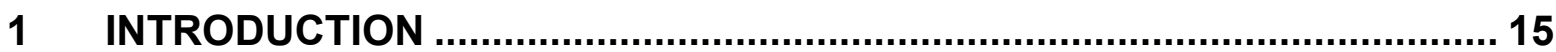

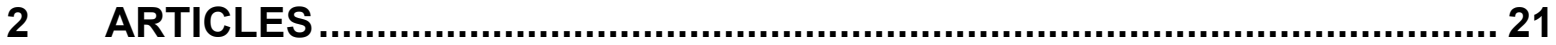

2.1 ARTICLE 1 the effect of orthodontic separator and short term fixed orthodontic appliance on inflammatory mediators and somatosensory function

2.2 ARTICLE 2 conditioned pain modulation efficiency can influence pain intensity, somatossensory function or inflammatory mediators in patients undergoing orthodontic treatment?

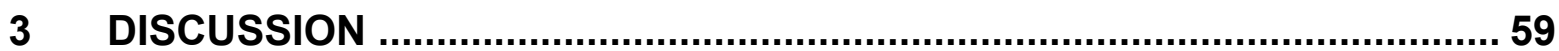

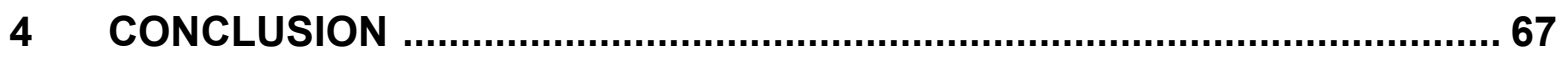

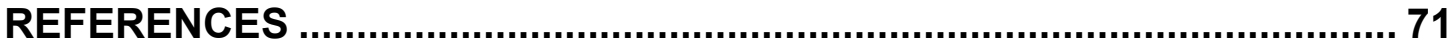



1. Introduction 





\section{INTRODUCTION}

Inflammation is local biological process that induces redness, heat, swelling, pain, and inhibited function (1). But, not always does signs are considered harmful. Some dental specialty needs inflammation process to occur in order to have success, such as dental implant osseointegration, healing after extraction and orthodontic tooth movement (OTM).

Pain is defined by the International Association for the Study of Pain (IASP) as "an unpleasant sensory and emotional experience associated with actual or potential tissue damage, or described in terms of such damage" (2). Orthodontic pain is one of the most unpleasant reactions to orthodontic therapy, and sometimes can lead to patient's treatment discontinue.

Some studies shows that the discomfort initiates in the first hours after the inserted force and can prolong up to 5 days (3), decreasing in intensity after day seven $(4,5)$. Bergius et al., 2002 (6), observed that the pain intensity is higher 24 hours after orthodontic separator placement decreasing gradually after a week. No study has compared pain intensity between orthodontic separators and comprehensive fixed appliances.

It is well establish how OTM induces local inflammation and pain, but the individual response it is not predictable. Conditioned Pain Modulation (CPM) is used to describe psychophysical paradigm designed to assess the Endogenous Analgesia, i.e. mechanism that can control or reduce pain, (pain reducing pain). This mechanism is assessing by applying two remote noxious stimuli which one ("conditioning stimulus"-CS) affects the perception of the other ("test stimulus" - TS) $(7,8)$. CPM efficiency may help to identify patients "at risk" for the development of chronic pain (9). So, it may help to identify why some patients report higher pain intensity following OTM.

Previous study has shown association between various chronic pain conditions such as temporomandibular disorders $(10,11)$, irritable bowel syndrome (10), fibromyalgia (12) and tension-type headache (13) with impaired and/or inefficient endogenous pain inhibition system (less efficient CPM). CPM paradigm has also been reported as a potential tool for understanding treatment mechanisms (14).

The incidence of pain may be associated with the interactions of inflammatory mediator (15-17), known to be released following by orthodontic force application that exceeds the bioelastic limits (18-20). Cytokines are proteins that act as signals between the cells of the immune system (21). Some studies reported the importance of pro-inflammatory 
cytokines, such as Prostaglandins (PGs), Interleukin 1- $\beta$ (IL-1 $\beta$ ), Interleukin 6 (IL-6), Interleukin 8 (IL-8) and the tumor necrosis factor alfa (TNF- $\alpha$ ), in the bone remodeling process induced by orthodontic forces $(16,19-21)$.

Furthermore, Giannopoulou et al. (17) suggested that pain intensity following OTM is associated with the initial levels of prostaglandins (PGE2) (1 hour after OTM) and interleukin $1 \beta$ (24h after OTM). Those chemical mediators are present in the gingival crevicular fluid (GCF) even after the application of low intensity forces, such as orthodontic separators (22). Those pro-inflammatory cytokines it also been reported to play an important role in pain induced by perineural inflammation in rats (23).

IL-6 is a pro-inflammatory cytokine known to be relating to tissue destruction in the periodontal site (24) with higher levels in inflamed gingival tissues when compared to noninflamed (25), that regulates immune responses in inflammation sites (26). Shimizu et al. (27) demonstrated that IL-6 was produced by IL-1 from periodontal ligament (PDL) cells. IL-1 plays an important role in inflammatory process and is mainly involved in bone metabolism, stimulation of bone resorption and inhibition of bone formation (28). Moreover, it may act synergistically with TNF- $\alpha$ (29. TNF- $\alpha$ is also present in sites of inflammation and regulates augmentation of bone resorption (Yamaguchi, 2005 \#17).

The cytokines level it is higher in adolescents when compared to adults during OTM (30), which may explain why younger patients has faster treatment since cytokines level is know to have a positive relation to tooth movement velocity (31).

Inflammation can also alter nerve function, and it has been shown that the release of IL-1 $\beta$ and TNF- $\alpha$ induce inflammatory hyperalgesia, characterized by decrease in the nociception threshold and increase neuronal membrane excitability (32). These somatosensory sensitivity can be measured with Quantitative Sensory Testing (QST), an extensively studied non-invasive method (33-36). The QST helps assessing the nervous system function (37) by evaluating the patient's response to a series of peripheral stimuli.

Several QST modalities are reported in the literature to evaluate somatosensory alteration. Different nerve fibers can be tested upon the test performed. A $\beta$ fibers, i.e. fast, thicker myelinated fibers, are assessed by electrical stimulation and mechanical touch. Nociceptive and thermal stimuli are transmitted by two different nerve fibers, A $\delta$, i.e. slow, thinner myelinated fibers, and C fibers, i.e slower, no-myelinated fibers (33). Unfortunately, there is no normative parameter to analyze QST results; in this way the comparison between the non-affected contra-lateral site (38) or before intervention is suggested. 
Recent studies have reported disturbance in somatosensory function following fixed orthodontic appliance (39-41), however to the best of our knowledge, no studies investigated a possible correlation of the cytokines and pain intensity with those findings.

Based on that, the aim of the present study was to investigate the impact of orthodontic separator and short-term fixed orthodontic appliance on the somatosensory function and gingival cervicular fluid (GCF) levels of IL-1 $\beta$, IL-8, IL-6 and TNF- $\alpha$. It is hypthozied that orthodontic separator and short-term fixed orthodontic appliance would impact the somatosenroy function and GCF levels of cytokines and that patient CPM efficient can influence those outcomes. 

2. Articles 



\section{ARTICLES}

The articles presented in this Thesis were written according to The Journal of Orofacial Rehabilitation instructions and guidelines for articles submission. 


\subsection{ARTICLE 1}

Title: THE EFFECT OF ORTHODONTIC SEPARATOR AND SHORT-TERM FIXED ORTHODONTIC APPLIANCE ON INFLAMMATORY MEDIATORS AND SOMATOSENSORY FUNCTION

Short Title: ORTHODONTIC PAIN ON SOMATOSENSORY FUNCTION

Article Category: Original research

${ }^{a, b}$ Fernanda A. Sampaio; ${ }^{c}$ Claudine R. A. Sampaio; ${ }^{a, d}$ Carolina O. Cunha; ${ }^{a, e}$ Yuri M. Costa; ${ }^{a, e}$ Leonardo R. Bonjardim; 'Daniela Garib; ${ }^{9}$ Gustavo P. Garlet; ${ }^{\text {h}}$ Eli Eliav; ${ }^{\mathrm{a}}$ Paulo C. R. Conti

${ }^{a}$ Department of Prosthodontics and Bauru Orofacial Pain Group, University of São Paulo, Bauru, Brazil;

${ }^{\mathrm{b}}$ Department of Prosthodontics, University Center Christus, Fortaleza, Brazil.

${ }^{\mathrm{c}}$ Dentistry Specialty Center (CEO), Fortaleza, Brazil

${ }^{\mathrm{d}}$ Health Science Center, Sacred Heart University, Bauru, Brazil

${ }^{\mathrm{e}}$ Section of Head and Face Physiology, Department of Biological Sciences, Bauru School of Dentistry, University of São Paulo, Bauru, Brazil;

'Department of Orthodontics, Bauru Dental School, University of São Paulo, Bauru, Brazil

${ }^{9}$ Department of Biological Sciences, School of Dentistry of Bauru, University of São Paulo (FOB/USP), Bauru, São Paulo, Brazil.

${ }^{\text {h}}$ Professor and Director, Eastman Institute of Oral Health, University of Rochester Medical Center, Rochester, NY, USA.

Corresponding Author

Ms. F. A. Sampaio

University Center Christus

R. João Adolfo Gurgel, 133 - Cocó,

Fortaleza - CE, 60190-060 - Brazil

fernandasamp@hotmail.com

Phone: +55-85-988999251 


\section{ABSTRACT}

Experimental tooth movement has been shown to induce inflammation and release of chemical mediators. Inflammation can also alter nerve function that can be measured with Quantitative Sensory Testing (QST). The aim of the present study was to investigate the impact of orthodontic separator and short-term fixed orthodontic appliance on the somatosensory function and gingival cervicular fluid (GCF). Thirty patients were evaluated as follow: baseline, $24 \mathrm{~h}$-after elastomeric separator (24h-aES), $24 \mathrm{~h}$ and 1 month after bonding the fixed appliance (aBFA) at maxillary and mandibular arch. The outcome variables were: self-reported pain (Visual Analog Scale, QSTs (current perception threshold (CPT), cold detection threshold (CDT), warm detection threshold (WDT), mechanical detection threshold (MDT), mechanical supra threshold (MST) and wind-up ratio (WUR) and sample from the gingival crevicular fluid (GCF) in order to assess cytokines profile (IL-1 $1 \beta$, IL-8, IL-6 and TNF-a). ANOVA and Tukey's post hoc analyses were performed $(a=5 \%)$. Patients were less sensitive to pin prick pain $(\mathrm{MST})$ at $24 \mathrm{~h}(\mathrm{p}<0.020)$ and 1 month-aBFA $(\mathrm{p}<0.002)$ when compared to baseline. Significant increases in IL-6 levels were observed 24h-aBFA $(p<0.023)$ and in IL-1 $\beta(p<0.001)$ and TNF-a $(p<0.026)$ levels at 1 month-aBFA when compared to baseline values $(p<0.023)$. In conclusion, orthodontic-induced inflammation may have a modality specific effect on somatosensory function of the trigeminal system. In addition, elastic separators seems not an ideal model to study possible inflammatory changes following orthodontic tooth movement.

Keywords: Orthodontic Appliances; Pain; Cytokines; Quantitative Sensory Testing; Gingival Crevicular Fluid 


\section{BACKGROUND}

Orthodontic pain is one of the most unpleasant reactions to orthodontic therapy. Some studies shows that the discomfort initiates in the first hours after the inserted force and can prolong up to 5 days (1), decreasing in intensity after day seven (2, 3). Bergius et al., $2002(4)$, observed that the pain intensity is higher 24 hours after orthodontic separator placement decreasing gradually after a week. No study has compared pain intensity between orthodontic separators and comprehensive fixed appliances.

Tooth movement is induced by orthodontic force application that exceeds the bioelastic limits of the tooth supporting tissue causing a local inflammation (5). Indeed, all inflammation's characteristics are present in the periodontal ligaments: redness, heat, swelling, pain, and inhibited function (6).

Experimental tooth movement has been shown to induce inflammation and release of chemical mediators (7-9). The incidence of pain may be associated with the interactions of inflammatory mediator $(10,11)$. Furthermore, some studies reported the importance of proinflammatory cytokines, such as Prostaglandins (PGs), Interleukin 1- $\beta$ (IL-1 $\beta$ ), Interleukin 6 (IL-6), Interleukin 8 (IL-8) and the tumor necrosis factor alfa (TNF-a), in the bone remodeling process induced by orthodontic forces (8-10). Those chemical mediators are present in the gingival crevicular fluid (GCF) even after the application of low intensity forces, such as orthodontic separators (12). Proinflammatory cytokines such as IL-1 $\beta$ and IL-6 have been shown to play an important role in pain induced by perineural inflammation in rats (13) .

Inflammation can also alter nerve function, and it has been shown that the release of IL-1 $\beta$ and TNF-a induce inflammatory hyperalgesia, characterized by decrease in the nociception threshold and increase neuronal membrane excitability (14). These somatosensory sensitivity can be measured with Quantitative Sensory Testing (QST), an extensively studied non-invasive method $(15,16)$. The QST helps assessing the nervous system function (17) by evaluating the patient's response to a series of peripheral stimuli.

Recent studies have reported disturbance in somatosensory function following fixed orthodontic appliance (18-20), however to the best of our knowledge, no studies investigated a possible correlation of the cytokines and pain intensity with those findings. 
Based on that, the aim of the present study was to investigate the impact of orthodontic separator and short-term fixed orthodontic appliance on the somatosensory function and gingival cervicular fluid (GCF) levels of IL-1 $1 \beta$, IL-8, IL-6 and TNF-a. It is hypthozied that orthodontic separator and short-term fixed orthodontic appliance would impact the somatosenroy function and GCF levels of cytokines.

\section{METHODS}

\section{Participants}

A total of 30 patients (22 females and 8 males) seeking for orthodontic treatment at Bauru Dental School, University of São Paulo, from May/2015 to November/2016, with a mean age of 14 years old were recruited for the study. The local Human Research Ethics Committee approved this study (Protocol and approval \#37635614.8.0000.5417). All participants and legal responsible, when necessary, gave their voluntary consent, after a full explanation of the research and procedures. The inclusion criteria were patients with complete natural dentition (exception of third molars), patients treated nonextraction with comprehensive fixed orthodontic appliance, good health with no orofacial pain complaints or chronic pain disorders that could influence normal somatosensory function. Exclusion criteria were orthodontic treatment in the past 6 months, active caries or periodontal disease, intake of medication, such as analgesics, opioids, antidepressants, anticonvulsants, and steroidal or non-steroidal anti-inflammatories during the evaluation period or 3 days before the study onset.

\section{Study Design}

All participants were evaluated in eight sessions by a single investigator (FAS) [baseline prior to any orthodontic intervention (1), 24h-after elastomeric separator - maxillary arch (2); $24 \mathrm{~h} \mathrm{(3)}$ and 1 month (4) after bonding the fixed appliance - maxillary arch; placement of elastomeric separator - mandibular arch (5); 24h-after elastomeric separator - mandibular arch (6); 24h (7) and 1 month (8) after bonding the fixed appliance - mandibular arch] as showed on Figure 01. The study was conducted in a quiet and isolated room, free from distractions. Data on self-reported pain (Visual Analog Scale (VAS), battery of QSTs \{electrical detection threshold (CPT); thermal threshold [cold detection threshold (CDT), warm detection threshold (WDT)]; mechanical threshold [mechanical 
detection threshold (MDT), mechanical supra threshold (MST), wind-up ratio (WUR)]\} and sample from the gingival crevicular fluid (GCF) in order to assess cytokines profile, were collected. The somatosensory profile was assessed, in a randomized order, on the skin overlying the infra-orbital nerve, for the maxillary arch, and the mental nerve for the mandibular arch. In addition, the GCF was collected from the bilateral molars and premolars teeth from both arches.

\section{Orthodontic intervention}

All patients initiated the orthodontic treatment in the maxillary arch following by mandibular arch. Only after finishing all the maxillary analyses the orthodontic treatment at the mandibular arch was initiated. Subjects were evaluated following two different orthodontic intervention: 1) after placement of orthodontic elastomeric separators at mesial and distal sides of first molar, bilaterally, on maxillary arch and then, on mandibular arch; 2) after brackets were bonded on 10 teeth, including second premolars and first molars and a NiTi 0.014 archwire was placed for leveling. Patients were evaluated in 7 different timepoints: Baseline (1), 24h-after separator on maxillary arch (2) 24h (3) and 1 month (4) after bonding orthodontic appliance on maxillary arch; $24 \mathrm{~h}$-after separator on mandibular arch (5), 24h (6) and 1 month (7) after fixed appliance on mandibular arch.

\section{Pain assessment}

All subjects were asked to evaluate their pain intensity on a VAS $(10 \mathrm{~cm}$ horizontal line with "No Pain" written in one extremity and "Worst Pain" in the other). Patients were asked to mark a vertical line crossing the horizontal line corresponding to their pain intensity. Pain intensity measurement was the distance between the beginning of the horizontal line, corresponding to $0 \mathrm{~cm}$, to the vertical line, drawed by the patient. The patients were asked to inform their pain intensity in each time point: baseline (1); Immediately (2) and 24h (3) after separator - maxillary arch; Immediately (4), 24h (5) and 1 month (6) after fixed orthodontics appliance - maxillary arch; Immediately (7) and 24h (8) after separator - mandibular arch; Immediately (9), 24h (10) and 1 month (11) after fixed orthodontics appliance - mandibular arch (19).

\section{Somatosensory assessment}

A standardized quantitative somatosensory evaluation was performed. Four of the total of 6 tests assed was performed according the recommendations of the DFNS (16): cold detection 
threshold (CDT), warm detection threshold (WDT), mechanical detection threshold (MDT) and wind-up ratio (WUR). In addition two more tests were added to the protocol: current perception threshold (CPT) and mechanical suprathreshold (MST).

CPT was measured using an electro diagnostic sensory nerve testing equipment (Neurometer NervScan- NS3000). A continuous train of constant-current electrical stimuli was delivered to the skin through two 8-mm-diameter spherical gold-plated electrodes spaced $20 \mathrm{~mm}$, coated with $0.3 \mathrm{~mL}$ of electroconductive gel. Each site received 3 stimulus frequencies, which are known to stimulate A-beta $(2,000 \mathrm{~Hz})$, A-delta $(250 \mathrm{~Hz})$, and C-fibers $(5 \mathrm{~Hz})$. During the entire test, subjects held a remote control used to stop the electrical stimulus. The instrument started the delivery of current for each specific frequency at the lowest output intensity and increased it until the patient perceived (and released the remote control button) an electrically evoked sensation, but not pain, or until the maximal stimulus was reached (output intensity range of 0.01 to $9.99 \mathrm{~mA}$ ). The device automatically repeated a minimum of 3 sets of testing for each frequency until the software determined a threshold $(21,22)$.

Thermal Thereshold (CDT and WDT) tests were performed using a $15 \times 15 \mathrm{~mm}$ water-cooled Peltier probe (Medoc - TSA II NeuroSensory Analyzer 2001). All thresholds were obtained with ramped stimuli $\left(1^{\circ} \mathrm{C} / \mathrm{s}\right)$, either increased (WDT) or decreased $(\mathrm{CDT})$, that were terminated when the subject pressed a button. The baseline temperature was $32^{\circ} \mathrm{C}$ and the cut-off temperature were 0 and $50{ }^{\circ} \mathrm{C}$. The mean threshold temperature of three consecutive measurements was calculated for CDT and WDT (16)

$M D T$ was performed as previously described $(16,18,23)$ using a standardized set of Semmes-Weinstein mono-filaments*, which apply forces between $0.008 \mathrm{~g} / \mathrm{mm}^{2}$ and $300 \mathrm{~g} / \mathrm{mm}^{2}$. Participants were instructed to report the first perception of touch. The 'method of limits' technique was used to determine the threshold, where a series of ascending and descending stimuli intensities were applied yielding five suprathreshold and five subthreshold reports. The MDT was the geometric mean of these five series $(16,18,23)$.

MST was tested using a pre-calibrated instrument (Semmes-Weinstein mono-filaments), which applied $60 \mathrm{~g} / \mathrm{mm}^{2}$ force. Participants were instructed to evaluate their amount of discomfort using a '0-100' numerical rating scale (NRS). The mean pain intensity of three consecutive measurements was calculated for MST. 
WUR was tested with a mono-filaments pre-calibrated to delivered $60 \mathrm{~g}$ force. The participants were asked to rate their pain intensity, using a ' $0-10$ ' NRS, of a single 'pinprick' stimulus and then after a series of 10 repetitive 'pinprick' stimuli of the same physical intensity (1/s applied within an area of 1 $\mathrm{cm}^{2}$ ). The procedure was repeated five times. The WUR was the mean rating of the five series divided by the mean rating of the five single stimuli $(16,23)$

\section{Gingival crevicular fluid (GCF) collection}

The GCF samples were collected from the bilaterally posterior teeth of the experimental arch (first maxillary and than mandibular) at baseline, 24h/separator, 24h/ortho and 1 month/ortho. Prior to GCF sampling, the supragingival plaque was removed with a sterile curet; the surfaces were gently dried by an air syringe and then isolated by cotton rolls. Paper strips were carefully inserted into the crevice until mild resistance was felt and were left in place for 30 seconds. Strips contaminated with blood were discarded. The strips were placed into sterile microtube vials and kept at $-70^{\circ} \mathrm{C}$ until analyzed (24).

\section{Enzyme-Linked Immunosorbent Assays (ELISAs)}

Measurements of cytokines in periodontal tissues were performed as previously described $(24,25)$. The concentrations of cytokines in periodontal extracts were determined by ELISA test using commercially available kits (all from R\&D Systems, Minneapolis, MN) as follows: IL-1ß (sensitivity > $0.063 \mathrm{pg} / \mathrm{ml}$ ), IL-6 (sensitivity $>0.11 \mathrm{pg} / \mathrm{ml}$ ), IL-8 (sensitivity $>0.4 \mathrm{pg} / \mathrm{ml}$ ) e TNF-a $(>0.049 \mathrm{pg} / \mathrm{mL}$ ). All assays were carried out according to the manufacturer's instructions. The results were expressed as picograms of cytokine $( \pm S D)$ per milligram of periodontal tissue, for one experiment representative of three.

\section{STATISTICAL ANALYZES}

Quantitative variables (age, CPT, MDT, MST, WUR, CDT, WDT, VAS) were reported as means \pm SD. All the quantitative variables were assessed for normal distribution using the Kolmogorov-Smirnov test and a log10 transformation was performed when the test results were significant, considering an alpha level of $5 \%(p<0.050)$.

Multi-way within-subjects analysis of variance (ANOVA) was performed as following: a) intervention (4 levels), nerve branch (2 levels) and fiber type (3 levels) were established to compare 
the absolute values of CPT (after log10 transformation); b) intervention (4 levels) and nerve branch (2 levels) were established to compare the absolute values of MDT, MST, WUR, CDT and WDT (after log10 transformation) and IL-1 $\beta$, IL-6, IL-8 and TNF- $\alpha$; $c$ ) intervention (6 levels) and nerve branch (2 levels) were established to compare the absolute values of VAS (after $\log 10$ transformation). When appropriate, post hoc analyses were performed using Tukey's Honestly Statistical Difference (HSD). The significance level was set at $5 \%(p=0.050)$.

\section{RESULTS}

A total of 30 patients (22 females and 8 males) with a mean age of 14 years old were included in the study. Drop-outs and missing values were not included in the analysis, i.e., no imputation thecnique was used. Thus, the sample size throught the study was: baseline maxillary arch - $n=30$ and mandibular arch $-\mathrm{n}=29 ; 24 \mathrm{~h}$-after sep. maxillary arch $-\mathrm{n}=30$ and mandibular arch $-\mathrm{n}=29 ; 24 \mathrm{~h}$-after bonding maxillary arch $-\mathrm{n}=20$ and mandibular arch $-\mathrm{n}=21 ; 1$ month after ortho maxillary arch $-\mathrm{n}=19$ and mandibular arch $-\mathrm{n}=18$.

\section{VAS}

Patients reported higher pain intensity $24 \mathrm{~h}$ after bonding the fixed orthodontic appliance compared to baseline (Baseline maxillary arch $=0.0$ and mandibular arch $=0.0 ; 24 \mathrm{~h}$ after bonding maxillary arch $-4.59 \pm 2.69$ ) and mandibular arch- 4.14 \pm 2.02 ; Turkey: $\mathrm{p}<0.001$ ) (Figure 02). There was no significant difference between the maxillary and mandibular arches. Moreover, there was no difference between pain felt immediate after separator and archwire assessment compared to baseline $(p=0.450)$.

\section{QST}

Overall, the infra-orbital nerve was more sensitive to the following QST (Tukey test results): CPT $(p=0.005)$, WDT $(p=0.019)$ and MST $(p=0.018)$ and less sensitive to MDT ( $p=0.022)$ and CDT $(p=0.039)$ when compared to mental nerve. But, no significant time changes were found for all detection threshold tests. However, patients were less sensitive to pin prick pain (MST) at $24 \mathrm{~h}$ $(p<0.020)$ and 1 month after fixed orthodontic appliance compared to baseline $(p<0.002)($ Table 01$)$. Table 02 shows all QST outcomes (mean \pm SD).

\section{Cytokines}


The results are expressed as picograms of cytokine $( \pm S D)$ per milligram of periodontal tissue (pg/ml). There was a trend of increase in IL-1 $1 \beta, \mathrm{IL}-6$ and TNF-a levels $24 \mathrm{~h}$-after separator placement but no significant difference was found when compared to baseline values. Table 03 shows all cytokines outcomes (mean \pm SD). The $p$ values were obtained from Tukey test.

Significant increases in IL-6 levels were observed 24h-after bonding the fixed appliance (v2 -

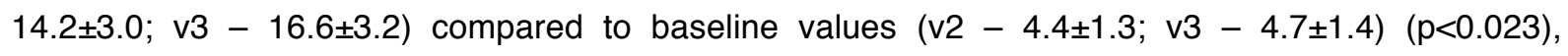
thereafter decreasing with no significance compared to baseline at 1 month-after-appliance (Table 04). Multiple comparison analysis showed significant increase in IL-1 $\beta$ levels $(p<0.001)$ and TNF- $\alpha$ $(p<0.026) 1$ month after bonding the orthodontic fixed appliance compared to baseline. No significant difference was found to IL-8 concentration at any time.

\section{DISCUSSION}

To our knowledge, the present study is the first to evaluate a possible association of inflammatory mediator, pain and somatosensory function following orthodontic procedures. The results showed that patients reported more pain $24 \mathrm{~h}$-after fixed orthodontic appliance when compared to baseline. The orthodontic treatment was associated with less sensitivity to a pin-prick stimulation $24 \mathrm{~h}$ and 1 month-after fixed appliance bonding, but no changes were found in MDT or thermal detection thresholds. There was a trend of increase in IL-1 $\beta$, IL- 6 and TNF- $\alpha$ levels $24 \mathrm{~h}$-after tooth separation but no significant difference was found when compared to baseline values. The IL-6 levels were significantly increased $24 \mathrm{~h}$-after bonding the orthodontic. However, the IL-1 $\beta$ and TNF-a were significantly higher only 1 month after treatment onset when compared to baseline.

In contrast to previous investigations, which applied either elastic separator around the first molars (11) (4) or fixed orthodontic appliance $(1-3,18,19)$ to induce pain, we decided to examine both methods of stimulating orthodontic tooth movement. Patients reported a moderate pain intensity $24 \mathrm{~h}-$ after bonding the fixed orthodontic appliance (mean VAS $=4.59 \pm 2.69(\mathrm{~V} 2)$ and $4.14 \pm 3.02(\mathrm{~V} 3)$ ) and only mild pain intensity following elastic separator (mean VAS $=2.0 \pm 2.80$ (V2) and $1.31 \pm 1.88(\mathrm{~V} 3)$ ), which were expected since the elastic separator only stimulate two contiguous teeth in contrast to the bonding fixed appliance which stimulate all teeth on the arch. Lv et al. reported similar amount of pain that peaks $24 \mathrm{~h}$-after orthodontic force (mean VAS $=4.2 \pm 1.8 \mathrm{~cm})(18)$. No significant differences were 
found when orthodontic-induced pain intensity at maxillary or mandibular arches were compared, suggesting that the pain intensity is independent of which arch is being stimulated. The higher pain intensity following fixed orthodontic appliance reported in this study maybe due to high levels of inflammation in the periodontal ligament between $12 \mathrm{~h}$ and $36 \mathrm{~h}$ following bonding $(7,8,14)$.

Although QST has been proven of high value in various orofacial pathologies, to our knowledge, only two studies $(18,19)$ applied it to patients undergoing orthodontic treatment and one study was conducted on a rat model (20). The study performed by Sood et al., 2015, shown a bilateral mechanical and thermal hypersensitivities following orthodontic tooth movement (OTM) model in rats, with peaks reached on postoperative day-1. However, the authors suggested that those somatosensory alterations could be results of a hyperocclusion-based hypersensitivity. Since the heavy intensity of the initial force used in this OTM rat model may lead to an immediate forced eruption of the tooth and thereby cause hyperocclusion and therefore not simulating the clinical condition in humans (20). The previous two clinical studies reported some site-specific somatosensory alteration. Lv et al. reported an alteration to pressure threshold in the attached gingiva and in the periodontal ligament $24 \mathrm{~h}$-following orthodontic appliance placement. Shen et al. found a hypersensitive to cold and hyposensitive to pressure at the site of the tooth movement up to 1 month after orthodontic force was applied. Both studies found some somatosensory alteration intra-orally, either at gingival site or directly to the crowns of the teeth, which diverge from the present study that the tests were performed extra-orally.

A review on neural mechanisms of nociception during orthodontic treatment published in 2017 by Kobayashi et al. (14) suggested that the release of IL-1 $\beta$ and TNF- $\alpha$ mediate inflammatory hyperalgesia by generating the release of prostaglandins (PGs), which sensitize nociceptors on Cfibers. Even though the present study show an increase in those two proinflammatory cytokines 1 month after initiate orthodontic force we could not find any hyperalgesia in the infra-orbital or mental nerves territory. This may be due to a site-specific effect discussed above. Moreover, there is no elevation on systemic cytokine-mediator following conventional orthodontic treatment (26), which may explain a site-specific effect. The results of the present study may suggest that orthodontic-induced inflammation, at least at the GCF, is insufficient to evoke significant change in mechanical and thermal threshold at extra-oral nerve territory. 
Endogenous analgesia (EA) is a mechanism that can control or reduce pain. The term Conditioned Pain Modulation (CPM) is used to describe psychophysical paradigm designed to assess the EA (pain reducing pain). This mechanism is assessing by applying two remote noxious stimuli which one inhibits the other (27). In the present study, the orthodontic fixed appliance was associated with decreased sensitivity to pin-prick pain $24 \mathrm{~h}$ and 1 month after beggining the treatment. Moreover, patient experienced more pain intensity $24 \mathrm{~h}$-after orthodontic fixed appliance, suggesting that maybe an EA effect is present, since two different noxious stimuli were applied (orthodontic force and pinprick test). However, patients were not experience pain 1 month following orthodontic treatment and they still report a hyposensitive to pin-prick stimuli. The exact mechanism underlying those results remain unknown but could be related to elevated levels of pro-inflammatory-cytokine at this time point.

The early phase of orthodontic tooth movement involves acute inflammatory responses, which induce the release of several inflammatory mediators to the GCF. The GCF analysis has been proven to be an effective method to identify specific biomarkers with reasonable sensitivity, therefore, an important tool to study PDL and alveolar bone remodeling (7). In the present study, apparently, there was a trend of IL-6, IL-1 $\beta$ and TNF- $\alpha$ increase $24 \mathrm{~h}$-after separator, however not significant when compared to baseline values. The orthodontic appliance, on the other hand, induced a significant increase in IL-6 levels after $24 \mathrm{~h}$ and in IL-1 $\beta$ and TNF- $\alpha$ levels after a month.

It has been shown in previous studies that the most commonly studied cytokines in association with orthodontic treatment are IL-1 $\beta, \mathrm{IL}-6, \mathrm{IL}-8$ and TNF- $\alpha(7,9)$, therefore those are the cytokines choosen to be evaluated in the present study. Manifold studies have showed increase in IL$1 \beta$ as early as $1 \mathrm{~min}$ to $1 \mathrm{~h}$ reaching peak at $24 \mathrm{~h}(7-9,11,28)$. But, Kappor et al., (7) reported, in a systematic review, studies showing a peak of IL-1 $\beta$ up to 6 months. In the present study, IL-1 $\beta$ levels peak one month after leveling. It is also imported to notice that light continuous force $(29,30)$ tended to maintain relatively high IL-1 $\beta$ levels for a longer period (9), which might explain why IL-1 $\beta$ levels show a tend to increase $24 \mathrm{~h}$-after separator but only peaks after 1 -month of continuous orthodontic force applied. Treatment mechanisms might be an important factor in the secretion regulation of those mediators and different cytokines may respond different to similar mechanisms (9). Moreover, inflammation along the nerve trunk (perineural inflammation) can cause neuritis. Eliav et al. reported significantly increased IL- 6 and IL-1 $\beta$ secretion by perineural inflammation induced in rats. The IL- 6 
was more prominent immediately following application when the pain peaked and reduced as the pain resolved. IL-1 $\beta$ activity remained elevated in a later stage after the resolution of the pain. This study might therefore support our finding of increased IL- 6 in early stage and IL-1 $\beta$ in a later stage.

Gender effect could not be studied due to the limited study sample. However, some studies suggested that estrous cycle might have an effect on mediator levels (7). Nevertheless, 1 month is a short effect compared to the long orthodontic time course; so, future longer-lasting studies should be performed to a better understanding of possible somatosensory changes along the whole orthodontic treatment. Additionally, it would be interesting to study the cytokines effect on intraoral-somatosensory profile.

In conclusion, orthodontic-induced inflammation may have a modality specific effect on somatosensory function of the trigeminal system, since we could not find significant differences in detection thresholds but only for pain sensitivity. In addition, elastic separators seems not an ideal model to study possible inflammatory changes following orthodontic tooth movement, since it only could induce mild pain and was not able to increase significantly pro-inflammatory cytokines level.

\section{Acknowledgments}

The local Human Research Ethics Committee approved the present study (Protocol and approval \# 37635614.8.0000.5417). This research was supported by São Paulo Research Foundation (FAPESP), grants \#2014/18741-0 and \#2015/09913-4 and by Coordination for the Improvement of Higher Level Personnel (CAPES). There were no conflicts of interest in this study. 


\section{TABLES}

Table 01. Multi-way within subjects ANOVA comparing intervention (baseline vs. immediate $24 \mathrm{~h}$-after sep. vs. $24 \mathrm{~h}$-after archwire vs. one month after archwire), nerve branch (infraorbital vs mental nerve) and fiber type (A-beta, A-delta and C) for current perception threshold (CPT) and intervention and nerve branch for different quantitative sensory testing (QST) parameters.

\begin{tabular}{|c|c|c|c|c|c|c|}
\hline & CPT & MDT & MST & WUR & CDT & WDT \\
\hline \multicolumn{7}{|l|}{ Main effects } \\
\hline \multicolumn{7}{|l|}{ Factors } \\
\hline 1-Intervention & $F=0.88, p=0.455$ & $\mathrm{~F}=2.21, \mathrm{p}=0.099$ & $\mathrm{~F}=5.49, \mathrm{p}=0.002$ & $F=0.62, p=0.605$ & $\mathrm{~F}=1.29, \mathrm{p}=0.288$ & $F=1.10, p=0.378$ \\
\hline 2-Nerve & $F=10.65, p=0.005$ & $\mathrm{~F}=6.53, \mathrm{p}=0.021$ & $\mathrm{~F}=6.95, \mathrm{p}=0.018$ & $F=0.36, p=0.561$ & $F=5.11, p=0.039$ & $F=6.80, p=0.019$ \\
\hline 3-Fiber & $F=386.16, p<0.001^{*}$ & NA & NA & NA & NA & NA \\
\hline \multicolumn{7}{|l|}{ Interactions } \\
\hline $1 \times 2$ & $F=0.80, p=0.496$ & $F=1.63, p=0.193$ & $F=1.33, p=0.273$ & $F=0.83, p=0.487$ & $F=1.90, p=0.142$ & $F=0.10, p=0.965$ \\
\hline $1 \times 3$ & $F=0.37, p=0.893$ & NA & NA & NA & NA & NA \\
\hline $2 \times 3$ & $F=7.44, p=0.002$ & NA & NA & NA & NA & NA \\
\hline $1 \times 2 \times 3$ & $F=0.56, p=0.758$ & NA & NA & NA & NA & NA \\
\hline
\end{tabular}

* Bold cells present significant $p$-values $(p<0.050)$

$\mathrm{CPT}=$ current perception threshold $(\mathrm{mA}) ; \mathrm{MDT}=$ mechanical detection threshold $\left(\mathrm{g} / \mathrm{mm}^{2}\right)$; MST = mechanical sensitivity threshold (pain intensity-VAS); WUR = wind-up ratio (pain intensity-VAS; CDT $=$ cold detection threshold $\left({ }^{\circ} \mathrm{C}\right)$; WDT $=$ warm detection threshold $\left({ }^{\circ} \mathrm{C}\right)$.

NA = Not applicable 
Table 02. Mean and standard deviation (s.d.) of the quantitative sensory testing at all time point.

\begin{tabular}{|c|c|c|c|c|}
\hline & Baseline & 24h-after elast sep & 24h-after ortho & 1 month after ortho \\
\hline \multicolumn{5}{|l|}{ CPT } \\
\hline \multicolumn{5}{|l|}{$2000 \mathrm{HZ}$} \\
\hline Infra-orbital n. & $158.6(71.6)$ & $163.1(99.4)$ & $189.3(138.3)$ & $176.7(74.9)$ \\
\hline Mental $\mathrm{n}$. & $145.8(137.2)$ & $173.5(92.4)$ & $168.2(81.3)$ & $207.8(109.1)$ \\
\hline \multicolumn{5}{|l|}{$250 \mathrm{HZ}$} \\
\hline Infra-orbital n. & $38.0(25.5)$ & $46.3(49.1)$ & $50.3(62.9)$ & $38.3(27.2)$ \\
\hline Mental $\mathrm{n}$. & $47.1(50.4)$ & $53.7(67.8)$ & $57.0(44.9)$ & $109.3(137.4)$ \\
\hline \multicolumn{5}{|l|}{$5 \mathrm{HZ}$} \\
\hline Infra-orbital n. & $19.6(18.2)$ & $26.1(39.8)$ & $27.6(32.5)$ & $23.4(22.5)$ \\
\hline Mental n. & $24.2(17.8)$ & $27.1(26.8)$ & $30.6(28.5)$ & $66.5(76.0)$ \\
\hline \multicolumn{5}{|l|}{ MDT } \\
\hline Infra-orbital n. & $0.13(0.24)$ & $0.15(0.28)$ & $0.13(0.29)$ & $0.11(0.26)$ \\
\hline Mental $\mathrm{n}$. & $0.10(0.24)$ & $0.14(0.33)$ & $0.09(0.16)$ & $0.05(0.09)$ \\
\hline \multicolumn{5}{|l|}{ CDT } \\
\hline Infra-orbital n. & $28.0(4.1)$ & $27.8(3.4)$ & $26.6(5.4)$ & $26.7(3.6)$ \\
\hline Mental $\mathrm{n}$. & $28.9(4.0)$ & $27.7(5.4)$ & $27.6(3.5)$ & $28.5(2.5)$ \\
\hline \multicolumn{5}{|l|}{ HDT } \\
\hline Infra-orbital n. & $34.9(2.8)$ & $34.9(1.8)$ & $35.3(2.1)$ & $35.3(1.7)$ \\
\hline Mental $\mathrm{n}$. & $35.8(3.5)$ & $35.3(2.2)$ & $36.1(2.0)$ & $36.1(1.9)$ \\
\hline \multicolumn{5}{|l|}{ MST } \\
\hline Infra-orbital n. & $2.7(2.6)$ & $2.3(2.6)$ & $2.4(2.7)$ & $1.6(2.2)$ \\
\hline Mental $\mathrm{n}$. & $2.5(2.6)$ & $1.7(1.9)$ & $1.8(2.4)$ & $1.8(2.4)$ \\
\hline \multicolumn{5}{|l|}{ WDT } \\
\hline Infra-orbital n. & $1.6(1.2)$ & $1.8(1.2)$ & $1.8(1.8)$ & $2.8(3.0)$ \\
\hline Mental $n$. & $2.3(2.3)$ & $2.7(3.0)$ & $2.0(1.6)$ & $2.2(2.7)$ \\
\hline
\end{tabular}

$\mathrm{CPT}=$ current perception threshold $(\mathrm{mA}) ; \mathrm{MDT}=$ mechanical detection threshold $\left(\mathrm{g} / \mathrm{mm}^{2}\right) ; \mathrm{MST}=$ mechanical sensitivity threshold (pain intensity-VAS); WUR = wind-up ratio (pain intensity-VAS; CDT $=$ cold detection threshold $\left({ }^{\circ} \mathrm{C}\right)$; WDT $=$ warm detection threshold $\left({ }^{\circ} \mathrm{C}\right)$.

$\mathrm{NA}=$ Not applicable 
Table 03. Mean and standard deviation (s.d.) of the cytokine concentration $(\mathrm{pg} / \mathrm{ml})$ at all time point.

\begin{tabular}{|c|c|c|c|c|}
\hline & Baseline & $24 \mathrm{~h}$-after elast sep & $24 \mathrm{~h}$-after ortho & 1 month after ortho \\
\hline \multicolumn{5}{|l|}{$\mathrm{IL}-1 \beta$} \\
\hline Infra-orbital n. & $25.0(8.1)$ & $35.4(5.4)$ & $41.5(6.7)$ & $56.8(9.2)$ \\
\hline Mental $\mathrm{n}$. & $24.6(7.3)$ & $33.3(5.4)$ & $41.5(6.2)$ & $53.4(6.8)$ \\
\hline \multicolumn{5}{|l|}{ IL-6 } \\
\hline Infra-orbital n. & $4.4(1.3)$ & $9.2(2.9)$ & $14.2(3.0)$ & $10.3(2.8)$ \\
\hline Mental n. & $4.7(1.4)$ & $9.9(3.1)$ & $16.6(3.2)$ & $11.1(2.0)$ \\
\hline \multicolumn{5}{|l|}{ IL-8 } \\
\hline Infra-orbital n. & $57.8(6.4)$ & $60.0(6.0)$ & $58.3(6.1)$ & $58.1(6.7)$ \\
\hline Mental $\mathrm{n}$. & $58.2(7.4)$ & $59.2(6.6)$ & $59.3(6.7)$ & $56.6(6.7)$ \\
\hline \multicolumn{5}{|l|}{ TNF-a } \\
\hline Infra-orbital n. & $21.8(3.3)$ & $30.7(4.6)$ & $35.9(4.1)$ & $38.0(4.2)$ \\
\hline Mental $\mathrm{n}$. & $21.9(4.1)$ & $31.6(5.6)$ & $34.0(5.2)$ & $37.6(7.3)$ \\
\hline
\end{tabular}

Table 4. Multi-way within subjects ANOVA comparing intervention (baseline vs. 24h-after elastic separator vs. 24h-after archwire vs. one moth after archwire) and nerve branch (infraorbital vs mental nerve) for different inflammatory mediators.

\begin{tabular}{|c|c|c|c|c|}
\hline & IL-1B & IL-16 & IL-18 & TNF-alfa \\
\hline \multicolumn{5}{|l|}{ Main effects } \\
\hline \multicolumn{5}{|l|}{ Factors } \\
\hline 1-Intervention & $F=135.32, p<0.001$ & $F=136.40, p<0.001$ & $F=2.85, p<0.047$ & $F=143.34, p<0.001$ \\
\hline 2-Nerve & $F=0.42, p=0.526$ & $\mathrm{~F}=2.95, \mathrm{p}=0.105$ & $F=0.01, p=0.912$ & $F=0.51, p=0.482$ \\
\hline \multicolumn{5}{|l|}{ Interactions } \\
\hline $1 \times 2$ & $F=0.46, p=0.705$ & $F=1.30, p=0.285$ & $F=1.51, p=0.222$ & $F=1.61, p=0.200$ \\
\hline
\end{tabular}

* Bold cells present significant $p$-values $(p<0.050)$ 


\section{FIGURE}

Figure 01. Flow chart representing the study design.

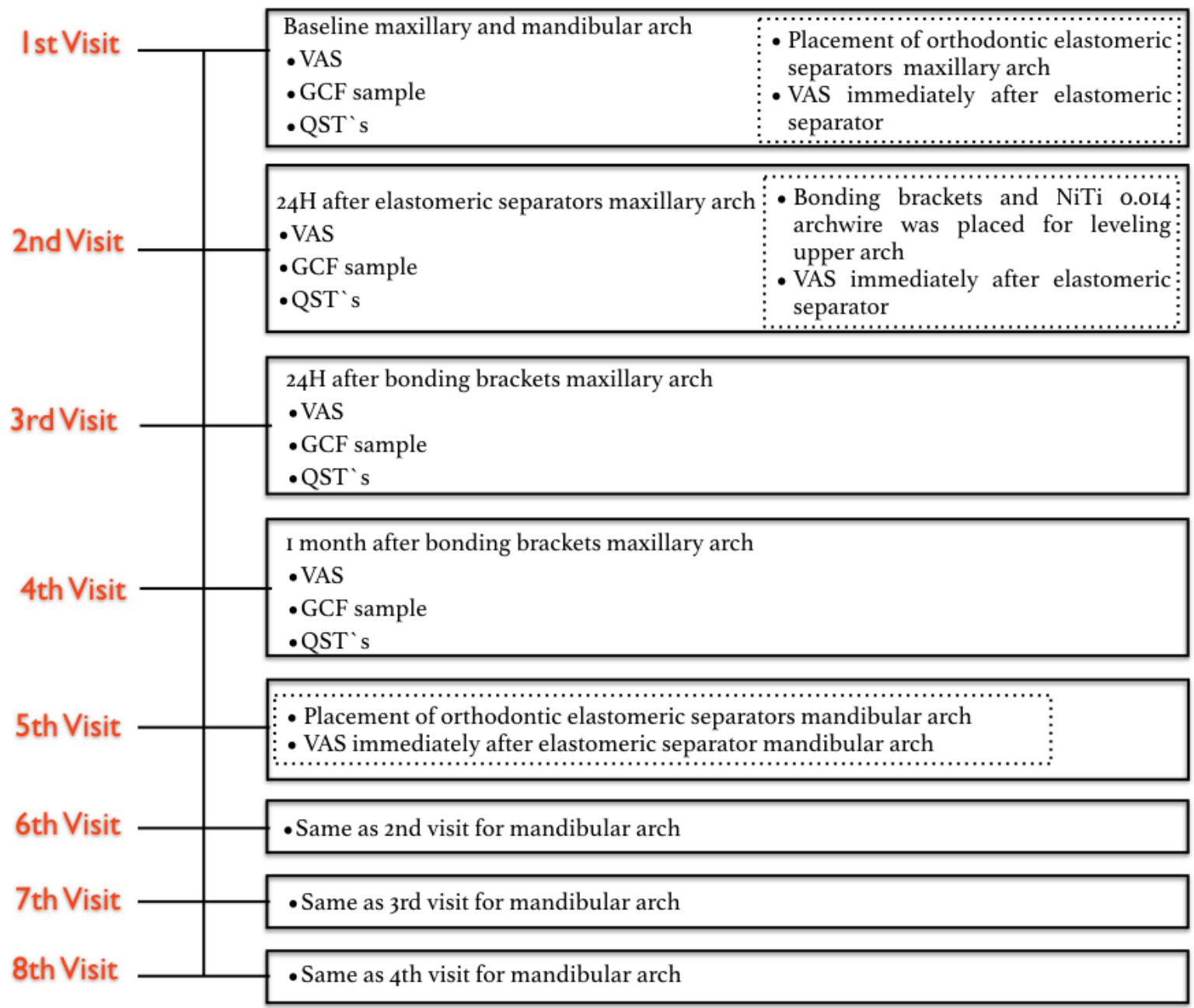

Figure 02. Pain intensity reported regardless all the visits at both arches (A: maxillary and B: mandibular arch)
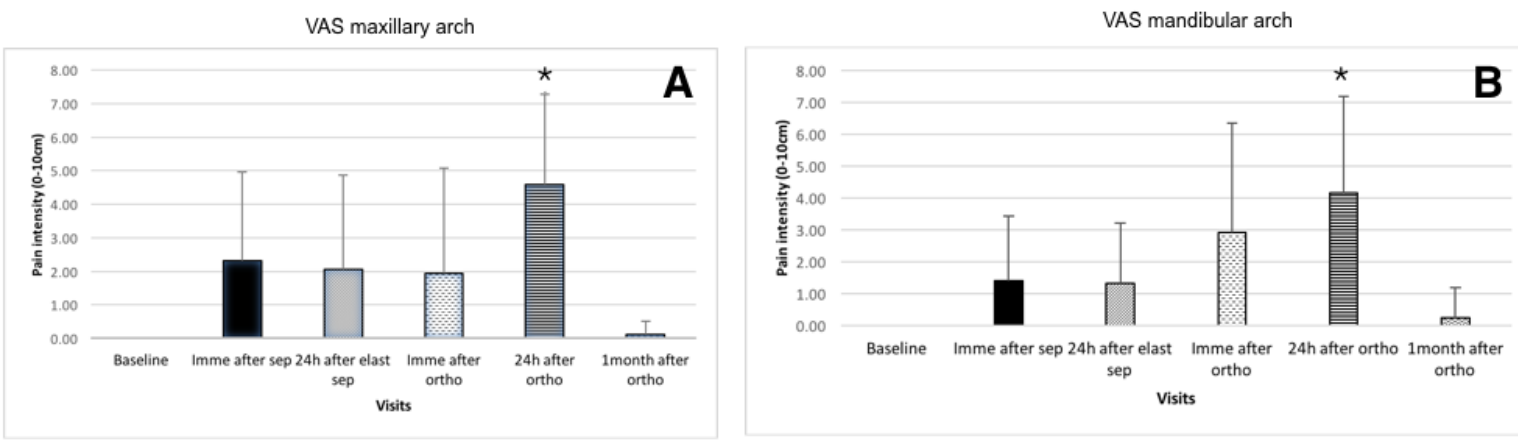


\section{REFERENCES}

1. Scheurer PA, Firestone AR, Burgin WB. Perception of pain as a result of orthodontic treatment with fixed appliances. European journal of orthodontics. 1996;18(4):349-57.

2. Ngan P, Kess B, Wilson S. Perception of discomfort by patients undergoing orthodontic treatment. American journal of orthodontics and dentofacial orthopedics : official publication of the American Association of Orthodontists, its constituent societies, and the American Board of Orthodontics. 1989;96(1):47-53.

3. Leavitt AH, King GJ, Ramsay DS, Jackson DL. A longitudinal evaluation of pulpal pain during orthodontic tooth movement. Orthodontics \& craniofacial research. 2002;5(1):2937.

4. Bergius M, Berggren U, Kiliaridis S. Experience of pain during an orthodontic procedure. European journal of oral sciences. 2002;110(2):92-8.

5. Davidovitch Z. Tooth movement. Crit Rev Oral Biol Med. 1991;2(4):411-50.

6. Brezniak N, Wasserstein A. Orthodontically induced inflammatory root resorption. Part

I: The basic science aspects. The Angle orthodontist. 2002;72(2):175-9.

7. Kapoor P, Kharbanda OP, Monga N, Miglani R, Kapila S. Effect of orthodontic forces on cytokine and receptor levels in gingival crevicular fluid: a systematic review. Prog Orthod. 2014;15:65.

8. Grant M, Wilson J, Rock P, Chapple I. Induction of cytokines, MMP9, TIMPs, RANKL and OPG during orthodontic tooth movement. European journal of orthodontics. 2013;35(5):644-51.

9. Ren Y, Vissink A. Cytokines in crevicular fluid and orthodontic tooth movement. European journal of oral sciences. 2008;116(2):89-97.

10. Grieve WG, 3rd, Johnson GK, Moore RN, Reinhardt RA, DuBois LM. Prostaglandin E (PGE) and interleukin-1 beta (IL-1 beta) levels in gingival crevicular fluid during human orthodontic tooth movement. American journal of orthodontics and dentofacial orthopedics : official publication of the American Association of Orthodontists, its constituent societies, and the American Board of Orthodontics. 1994;105(4):369-74.

11. Giannopoulou C, Dudic A, Kiliaridis S. Pain discomfort and crevicular fluid changes induced by orthodontic elastic separators in children. The journal of pain : official journal of the American Pain Society. 2006;7(5):367-76.

12. Dudic A, Kiliaridis S, Mombelli A, Giannopoulou C. Composition changes in gingival crevicular fluid during orthodontic tooth movement: comparisons between tension and compression sides. European journal of oral sciences. 2006;114(5):416-22.

13. Eliav E, Benoliel R, Herzberg U, Kalladka M, Tal M. The role of IL-6 and IL-1beta in painful perineural inflammatory neuritis. Brain Behav Immun. 2009;23(4):474-84.

14. Kobayashi M, Horinuki E. Neural mechanisms of nociception during orthodontic treatment. J Oral Sci. 2017;59(2):167-71.

15. Nasri-Heir C, Gomes J, Heir GM, Ananthan S, Benoliel R, Teich S, et al. The role of sensory input of the chorda tympani nerve and the number of fungiform papillae in burning mouth syndrome. Oral Surg Oral Med Oral Pathol Oral Radiol Endod. 2011;112(1):65-72.

16. Rolke R, Magerl W, Campbell KA, Schalber C, Caspari S, Birklein F, et al. Quantitative sensory testing: a comprehensive protocol for clinical trials. European journal of pain (London, England). 2006;10(1):77-88.

17. Sang CN, Max MB, Gracely RH. Stability and reliability of detection thresholds for human A-Beta and A-delta sensory afferents determined by cutaneous electrical stimulation. J Pain Symptom Manage. 2003;25(1):64-73. 
18. Lv D, Zhang J, Gu X, Shen H, Shao S, Hou W, et al. Transient Pain Following Orthodontic Fixed Appliances Induces Sensitization of Gingival and Periodontal Tissues. J Oral Facial Pain Headache. 2016;30(3):228-33.

19. Shen H, Shao S, Zhang J, Wang Z, Lv D, Chen W, et al. Fixed orthodontic appliances cause pain and disturbance in somatosensory function. European journal of oral sciences. 2016;124(1):26-32.

20. Sood M, Bhatt P, Sessle BJ. Mechanical and thermal hypersensitivities associated with orthodontic tooth movement: a behavioral rat model for orthodontic tooth movementinduced pain. J Oral Facial Pain Headache. 2015;29(1):60-9.

21. Ziccardi VB, Dragoo J, Eliav E, Benoliel R. Comparison of current perception threshold electrical testing to clinical sensory testing for lingual nerve injuries. $\mathrm{J}$ Oral Maxillofac Surg. 2012;70(2):289-94.

22. Porporatti AL, Bonjardim LR, Stuginski-Barbosa J, Bonfante EA, Costa YM, Rodrigues Conti PC. Pain from Dental Implant Placement, Inflammatory Pulpitis Pain, and Neuropathic Pain Present Different Somatosensory Profiles. J Oral Facial Pain Headache. 2017;31(1):19-29.

23. Costa YM, Morita-Neto O, de Araujo-Junior EN, Sampaio FA, Conti PC, Bonjardim LR. Test-retest reliability of quantitative sensory testing for mechanical somatosensory and pain modulation assessment of masticatory structures. Journal of oral rehabilitation. 2017;44(3):197-204.

24. de Oliveira RR, Schwartz-Filho HO, Novaes AB, Garlet GP, de Souza RF, Taba M, et al. Antimicrobial photodynamic therapy in the non-surgical treatment of aggressive periodontitis: cytokine profile in gingival crevicular fluid, preliminary results. Journal of periodontology. 2009;80(1):98-105.

25. Garlet GP, Cardoso CR, Silva TA, Ferreira BR, Avila-Campos MJ, Cunha FQ, et al. Cytokine pattern determines the progression of experimental periodontal disease induced by Actinobacillus actinomycetemcomitans through the modulation of MMPs, RANKL, and their physiological inhibitors. Oral Microbiol Immunol. 2006;21(1):12-20.

26. MacLaine JK, Rabie AB, Wong R. Does orthodontic tooth movement cause an elevation in systemic inflammatory markers? European journal of orthodontics. 2010;32(4):435-40.

27. Yarnitsky D, Arendt-Nielsen L, Bouhassira D, Edwards RR, Fillingim RB, Granot $\mathrm{M}$, et al. Recommendations on terminology and practice of psychophysical DNIC testing. European journal of pain (London, England). 2010;14(4):339.

28. Yamaguchi M, Yoshii M, Kasai K. Relationship between substance $\mathrm{P}$ and interleukin-1beta in gingival crevicular fluid during orthodontic tooth movement in adults. European journal of orthodontics. 2006;28(3):241-6.

29. Iwasaki LR, Crouch LD, Tutor A, Gibson S, Hukmani N, Marx DB, et al. Tooth movement and cytokines in gingival crevicular fluid and whole blood in growing and adult subjects. American journal of orthodontics and dentofacial orthopedics : official publication of the American Association of Orthodontists, its constituent societies, and the American Board of Orthodontics. 2005;128(4):483-91.

30. Lee KJ, Park YC, Yu HS, Choi SH, Yoo YJ. Effects of continuous and interrupted orthodontic force on interleukin-1beta and prostaglandin E2 production in gingival crevicular fluid. American journal of orthodontics and dentofacial orthopedics : official publication of the American Association of Orthodontists, its constituent societies, and the American Board of Orthodontics. 2004;125(2):168-77. 


\subsection{ARTICLE 2}

Title: CONDITIONED PAIN MODULATION EFFICIENCY CAN INFLUENCE PAIN INTENSITY, SOMATOSSENSORY FUNCTION OR INFLAMMATORY MEDIATORS IN PATIENTS UNDERGOING ORTHODONTIC TREATMENT?

Short Title: CONDITIONED PAIN MODULATION INFLUENCE ORTHODONTIC PAIN, SOMATOSENSORY FUNCTION AND INFLAMMATORY MEDIATOR

Article Category: Original research

${ }^{a, b}$ Fernanda A. Sampaio; ${ }^{C}$ Phillipe N. B. Alencar; ${ }^{a, d}$ Carolina O. Cunha; ${ }^{a, e}$ Yuri M. Costa; ${ }^{a, e}$ Leonardo

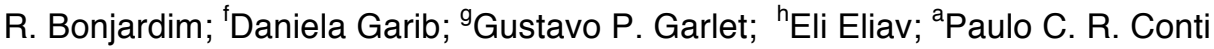

${ }^{a}$ Department of Prosthodontics and Bauru Orofacial Pain Group, University of São Paulo, Bauru, Brazil

${ }^{b}$ Department of Prosthodontics, University Center Christus, Fortaleza, Brazil

${ }^{c}$ Department of Radiology, University Center Christus, Fortaleza, Brazil.

${ }^{d}$ Health Science Center, Sacred Heart University, Bauru, Brazil

'Section of Head and Face Physiology, Department of Biological Sciences, Bauru School of Dentistry, University of São Paulo, Bauru, Brazil;

'Department of Orthodontics, Bauru Dental School, University of São Paulo, Bauru, Brazil

${ }^{9}$ Department of Biological Sciences, School of Dentistry of Bauru, University of São Paulo (FOB/USP), Bauru, São Paulo, Brazil.

${ }^{\mathrm{h}}$ Professor and Director, Eastman Institute of Oral Health, University of Rochester Medical Center, Rochester, NY, USA.

Corresponding Author

Ms. F. A. Sampaio

University Center Christus

R. João Adolfo Gurgel, 133 - Cocó,

Fortaleza - CE, 60190-060 - Brazil

fernandasamp@hotmail.com

Phone: +55-85-988999251 


\section{Abstract}

Endogenous analgesia $(E A)$ is a mechanism that can control or reduce pain. Conditioned Pain Modulation (CPM) is a psychophysical paradigm designed to assess EA in clinical research. CPM efficiency may help to identify patients "at risk" for the development of chronic pain. The aim of this study was to investigate the impact of CPM efficiency on pain intensity, somatosensory function and the release of inflammatory mediators at gingival crevicular fluid (GCF) in patients during orthodontic treatment. Thirty patients were evaluated as follow: baseline, 24h-after elastomeric separator (24h-aES), 24h and 1 month after bonding the fixed appliance (aBFA) at maxillary and mandibular arch. The outcome variables were: self-reported pain, QSTs (current perception threshold, cold detection threshold, warm detection threshold, mechanical detection threshold, mechanical supra threshold and wind-up ratio, CPM and sample from the GCF in order to assess cytokines profile (IL-1 $\beta$, IL-8, IL-6 and TNF- $\alpha$ ). The participants were divided in two groups: G1) RESPONDERS (more than 10\% decrease in WUR); G2) NON-RESPONDERS (not show more than $10 \%$ decrease in WUR). T-test for independent sample was performed. A Bonferroni correction lowered the significance level to $0.1 \%(p=0.001)$ as the cut-off point to establish the statistical significance for the mean difference between CPM responders and non-responders. There was no significant difference in somatosensory function, pain report and GCF cytokines when compared between G1 and G2. In conclusion, CPM efficiency may not significantly influence somatosensory function, pain intensity or released of inflammatory cytokines following orthodontic tooth movement up to $1 \mathrm{montH}$. However, remained to be confirmed and further investigations are required in intraoral somatosensory assessment.

Keywords: Orthodontic Appliances; Pain; Cytokines; Quantitative Sensory Testing; Gingival Crevicular Fluid, Conditioned Pain Modulation 


\section{Background}

Pain is defined by the International Association for the Study of Pain (IASP) as "An unpleasant sensory and emotional experience associated with actual or potential tissue damage, or described in terms of such damage" (1).

Endogenous analgesia $(E A)$ is a mechanism that can control or reduce pain. The term Conditioned Pain Modulation (CPM) is used to describe psychophysical paradigm designed to assess the EA (pain reducing pain). This mechanism is assessing by applying two remote noxious stimuli which one ("conditioning stimulus" - CS) affects the perception of the other ("test stimulus" TS) $(2,3)$.

Experimental tooth movement has been shown to induce pain (4) and released of various inflammatory chemical mediators at the gingival crevicular fluid (GCF) (5-7). Moreover, the incidence of pain may be associated with the interactions of inflammatory mediator (8). In addition, some studies suggested a disturbance in somatosensory function during orthodontic treatment (9$11),(12,13)$.

CPM efficiency may help to identify patients "at risk" for the development of chronic pain (14). Previous study has shown association between various chronic pain conditions such as temporomandibular disorders $(15,16)$, irritable bowel syndrome (15), fibromyalgia (17) and tensiontype headache (18) with impaired and/or inefficient endogenous pain inhibition system (less efficient CPM). CPM paradigm has also been reported as a potential tool for understanding treatment mechanisms (19).

Since orthodontic-induced tooth movement induces pain, the aim of this study was to investigate the impact of CPM efficiency on pain intensity, somatosensory function and the release of inflammatory mediators at GCF in patients during orthodontic treatment. It is hypothesized that CPM efficiency would influence the pain intensity, somatosensory function and GCF levels of cytokines during orthodontic treatment.

\section{Methods}

\section{Participants}

A total of 30 patients (22 females and 8 males) seeking for orthodontic treatment at Bauru Dental School, University of São Paulo, from May/2015 to November/2016, with a mean age of 14 
years old were recruited for the study. The local Human Research Ethics Committee approved this study (Protocol and approval \#37635614.8.0000.5417). All participants and legal responsible, when necessary, gave their voluntary consent, after a full explanation of the research and procedures. The inclusion criteria were patients with complete natural dentition (exception of third molars), treated nonextraction with comprehensive fixed orthodontic appliance, in good health, with no orofacial pain complaints or chronic pain disorders that could influence normal somatosensory function. Exclusion criteria were orthodontic treatment in the past 6 months, active caries or periodontal disease, intake of medication, such as analgesics, opioids, antidepressants, anticonvulsants, and steroidal or non-steroidal anti-inflammatories during the evaluation period or 3 days before the study onset.

\section{Study Design}

All participants were evaluated in eight sessions by a single investigator (FAS) [baseline prior to any orthodontic intervention (1), 24h-after elastomeric separator - maxillary arch (2); $24 \mathrm{~h}$ (3) and 1 month (4) after bonding the fixed appliance - maxillary arch; placement of elastomeric separator - mandibular arch (5); 24h-after elastomeric separator - mandibular arch (6); 24h (7) and 1 month (8) after bonding the fixed appliance - mandibular arch] as showed on Figure 01. The study was conducted in a quiet and isolated room, free from distractions. Data on self-reported pain (Visual Analog Scale (VAS), battery of QSTs \{electrical detection threshold (CPT); thermal threshold [cold detection threshold (CDT), warm detection threshold (WDT)]; mechanical threshold [mechanical detection threshold (MDT), mechanical supra threshold (MST), wind-up ratio (WUR)]\} and sample from the gingival crevicular fluid (GCF) in order to assess cytokines profile, were collected. The somatosensory profile was assessed, in a randomized order, on the skin overlying the infra-orbital nerve, for the maxillary arch, and the mental nerve for the mandibular arch. In addition, the GCF was collected from the bilateral molars and premolars teeth from both arches.

\section{Orthodontic intervention}

All patients initiated the orthodontic treatment in the maxillary arch following by mandibular arch. Only after finishing all the maxillary analyses the orthodontic treatment at the mandibular arch was initiated. Subjects were evaluated following two different orthodontic intervention: 1) after 
placement of orthodontic elastomeric separators at mesial and distal sides of first molar, bilaterally, on maxillary arch and then, on mandibular arch; 2) after brackets were bonded on 10 teeth, including second premolars and first molars and a NiTi 0.014 archwire was placed for leveling. Patients were evaluated in 7 different timepoints: Baseline (1), 24h-after separator on maxillary arch (2) $24 \mathrm{~h} \mathrm{(3)}$ and 1 month (4) after bonding orthodontic appliance on maxillary arch; $24 \mathrm{~h}$-after separator on mandibular arch (5), 24h (6) and 1 month (7) after fixed appliance on mandibular arch.

\section{Pain assessment}

All subjects were asked to evaluate their pain intensity on a VAS $(10 \mathrm{~cm}$ horizontal line with "No Pain" written in one extremity and "Worst Pain" in the other). Patients were asked to mark a vertical line crossing the horizontal line corresponding to their pain intensity. Pain intensity measurement was the distance between the beginning of the horizontal line, corresponding to $0 \mathrm{~cm}$, to the vertical line, drawed by the patient. The patients were asked to inform their pain intensity in each time point: baseline (1); Immediately (2) and 24h (3) after separator - maxillary arch; Immediately (4), 24h (5) and 1 month (6) after fixed orthodontics appliance - maxillary arch; Immediately (7) and 24h (8) after separator - mandibular arch; Immediately (9), 24h (10) and 1 month (11) after fixed orthodontics appliance - mandibular arch (10).

\section{Somatosensory assessment}

A standardized quantitative somatosensory evaluation was performed. Four of the total of 6 tests assed was performed according the recommendations of the DFNS (20): cold detection threshold (CDT), warm detection threshold (WDT), mechanical detection threshold (MDT) and wind-up ratio (WUR). In addition two more tests were added to the protocol: current perception threshold (CPT) and mechanical suprathreshold (MST).

CPT was measured using an electro diagnostic sensory nerve testing equipment (Neurometer NervScan- NS3000). A continuous train of constant-current electrical stimuli was delivered to the skin through two 8-mm-diameter spherical gold-plated electrodes spaced $20 \mathrm{~mm}$, coated with $0.3 \mathrm{~mL}$ of electroconductive gel. Each site received 3 stimulus frequencies, which are known to stimulate A-beta $(2,000 \mathrm{~Hz})$, A-delta $(250 \mathrm{~Hz})$, and C-fibers $(5 \mathrm{~Hz})$. During the entire test, subjects held a remote control used to stop the electrical stimulus. The instrument started the 
delivery of current for each specific frequency at the lowest output intensity and increased it until the patient perceived (and released the remote control button) an electrically evoked sensation, but not pain, or until the maximal stimulus was reached (output intensity range of 0.01 to $9.99 \mathrm{~mA}$ ). The device automatically repeated a minimum of 3 sets of testing for each frequency until the software determined a threshold $(21,22)$.

Thermal Thereshold (CDT and WDT) tests were performed using a $15 \times 15 \mathrm{~mm}$ watercooled Peltier probe (Medoc - TSA II NeuroSensory Analyzer 2001). All thresholds were obtained with ramped stimuli $\left(1^{\circ} \mathrm{C} / \mathrm{s}\right)$, either increased (WDT) or decreased (CDT), that were terminated when the subject pressed a button. The baseline temperature was $32{ }^{\circ} \mathrm{C}$ and the cut-off temperature were 0 and $50{ }^{\circ} \mathrm{C}$. The mean threshold temperature of three consecutive measurements was calculated for CDT and WDT (20)

MDT was performed as previously described $(9,20,23)$ using a standardized set of Semmes-Weinstein mono-filaments ${ }^{*}$, which apply forces between $0.008 \mathrm{~g} / \mathrm{mm}^{2}$ and $300 \mathrm{~g} / \mathrm{mm}^{2}$. Participants were instructed to report the first perception of touch. The 'method of limits' technique was used to determine the threshold, where a series of ascending and descending stimuli intensities were applied yielding five suprathreshold and five subthreshold reports. The MDT was the geometric mean of these five series $(9,20,23)$.

MST was tested using a pre-calibrated instrument (Semmes-Weinstein mono-filaments), which applied $60 \mathrm{~g} / \mathrm{mm}^{2}$ force. Participants were instructed to evaluate their amount of discomfort using a '0-100' numerical rating scale (NRS). The mean pain intensity of three consecutive measurements was calculated for MST.

WUR was tested with a mono-filaments pre-calibrated to delivered $60 \mathrm{~g}$ force. The participants were asked to rate their pain intensity, using a ' $0-10$ ' NRS, of a single 'pinprick' stimulus and then after a series of 10 repetitive 'pinprick' stimuli of the same physical intensity $(1 / \mathrm{s}$ applied within an area of $1 \mathrm{~cm}^{2}$ ). The procedure was repeated five times. The WUR was the mean rating of the five series divided by the mean rating of the five single stimuli $(20,23)$.

\section{CPM assessment}

The CPM paradigm was performed using two noxious stimulus according to the following: a) WUR, as described previews in this study, performed at two different site was the test stimulus (TS): (1) 
trigeminal site (skin underling infra-orbital nerve) and (2) spinal site (dominant arm); b) immersion of the participant's non-dominant hand up to the wrist in hot water bath maintained at $46.5{ }^{\circ} \mathrm{C}$ for 1 min was the conditioning stimulus (CS). The test stimulus was performed before and during the last 30 s of the CS (parallel protocol). Thus, the absolute and percent change difference between the values of "WUR during the CS" and "WUR before the CS" were considered as CPM (19). Pain inhibition along the protocol was represented by a negative value.

\section{Gingival crevicular fluid (GCF) collection}

The GCF samples were collected from the bilaterally posterior teeth of the experimental arch (first maxillary and than mandibular) at baseline, 24h/separator, 24h/ortho and 1month/ortho. Prior to GCF sampling, the supragingival plaque was removed with a sterile curet; the surfaces were gently dried by an air syringe and then isolated by cotton rolls. Paper strips were carefully inserted into the crevice until mild resistance was felt and were left in place for 30 seconds. Strips contaminated with blood were discarded. The strips were placed into sterile microtube vials and kept at $-70^{\circ} \mathrm{C}$ until analyzed $(24,25)$.

\section{Enzyme-Linked Immunosorbent Assays (ELISAs)}

Measurements of cytokines in periodontal tissues were performed as previously described $(25,26)$. The concentrations of cytokines in periodontal extracts were determined by ELISA test using commercially available kits (all from R\&D Systems, Minneapolis, MN) as follows: IL-1 $\beta$ (sensitivity $>0.063 \mathrm{pg} / \mathrm{ml}$ ), IL-6 (sensitivity $>0.11 \mathrm{pg} / \mathrm{ml}$ ), IL-8 (sensitivity $>0.4 \mathrm{pg} / \mathrm{ml}$ ) e TNF-a $(>0.049 \mathrm{pg} / \mathrm{mL}$ ). All assays were carried out according to the manufacturer's instructions. The results were expressed as picograms of cytokine $( \pm S D)$ per milligram of periodontal tissue, for one experiment representative of three.

\section{STATISTICAL ANALYSES}

Quantitative variables were reported as means and standard deviation (SD) and the sex distribution was presented in percentage. All the quantitative variables were assessed for normal distribution using the Kolmogorov-Smirnov test and a $\log _{10}$ transformation was applied when appropriate $(\mathrm{p}<0.050)$. 
The $95 \%$ confidence interval $(95 \% \mathrm{Cl})$ of the mean for the CPM relative changes was also computed in order to estimate population mean. In addition, the participants were divided in two groups according to the CPM percent changes considering the trigeminal site: responders, who showed more than $10 \%$ decrease in WUR; non-responders, who did not show more than $10 \%$ decrease in WUR (27). Finally, t-test for independent sample was computed to assess possible differences in the somatosensory function, pain report and GCF cytokines. In order to adjust for multiple comparisons, a Bonferroni correction lowered the significance level to $0.1 \%(p=0.001)$ as the cut-off point to establish the statistical significance for the mean difference between CPM responders and non-responders. We considered the group of electrical tests (Neurometer), QST, pain report, and the GCF as families of comparisons. Therefore, the family wise error rate was established considering 32 multiple comparisons (4 families $\times 2$ sites $\times 4$ assessments) and, according to the Bonferroni formula ( $0.05 / \mathrm{k}$, where $\mathrm{k}=$ number of comparisons), an alpha level as $p=0.001$ was set up. All tests were carried out using the software STATISTICA, v 10 (StatSoft Inc., USA).

\section{RESULTS}

A total of 30 patients (22 females and 8 males) with a mean age of 14 years old were included in the study. Dropouts and missing values were not included in the analysis, i.e., no imputation technique was used. Thus, the sample size through the study was: baseline maxillary jaw $-\mathrm{n}=30$ and mandibular jaw $-\mathrm{n}=29 ; 24 \mathrm{~h}$ after separation maxillary jaw $-\mathrm{n}=30$ and mandibular jaw $-\mathrm{n}=29 ; 24 \mathrm{~h}$ after bonding maxillary jaw $-\mathrm{n}=20$ and mandibular jaw $-\mathrm{n}=21 ; 1$ month after orthodontics maxillary jaw $-\mathrm{n}=19$ and mandibular jaw $-\mathrm{n}=18$.

Absolute mean (SD) differences between WUR obtained along the pain modulation protocol were $-0.2(1.4)[95 \% \mathrm{Cl}-0.8$ to 0.2$]$ for the trigeminal site and $0.3(3.4)[95 \% \mathrm{Cl}-0.9$ to 1.6$]$ for the spinal site. Relative mean (SD) changes between WUR obtained along the pain modulation protocol were $-16.9 \%(58.7)[95 \% \mathrm{Cl}-38$ to $4.9 \%)$ for the trigeminal site and $-1.0 \%(-93.8)[95 \% \mathrm{Cl}-$ 36 to $34 \%$ ] with no significant differences for the absolute or relative changes CPM between the groups $(p>0.050)$.

There was no significant difference in somatosensory function, pain report and GCF 
cytokines when compared between CPM responder (G1) and non-responder groups (G2). Except for CPT $-5 \mathrm{~Hz}$ baseline at mental n. $(\mathrm{G} 1: 30.1 \pm 18.4 ; \mathrm{G} 2: 19.1 \pm 6.0 ; p=0.029)$ and IL1 $-\beta$ baseline at infra-orbital n. (G1: $21.75 \pm 7.5 ; G 2: 27.93 \pm 7.8 ; p=0.026)$. Table 01 to 04 shows mean $\pm S D$ and $p$ value for all outcomes.

\section{DISCUSSION}

The results of this study did not support the hypothesis that CPM efficiency impacts pain intensity, somatosensory function and release of inflammatory cytokines following orthodontic tooth movement at any time point tested in this study. After the correction for multiple comparisons, no significant correlations were found.

The lack of significant association between CPM efficiency and the outcome variables of the present study after the adjustment for multiple comparisons was an interesting finding. Considering that CPM efficiency may help to identify patients "at risk" to develop chronic pain $\{$ Yarnitsky, $2008 \# 8\}$, significant association could be expected, at least between the reported pain intensity during orthodontic treatment, either after elastomeric separator or bonding fixed appliance. It is possible that could be explained by specific parameters of our CPM protocol.

A meeting happened in Florence (October 2013) brought together several researchers interested in CPM to discuss some issues regardless the CPM protocol. Yarnitsky et al., in 2015, published a summary of the experts-opinion-based protocol suggested by the forum. Even though the methods used in the present research was similar to many in common used $(20,22,23,28)$, it differs in some aspect from the research protocol suggested at the forum discussion. It is possible that the specific parameters of the present CPM testing contributed to the lack of association. In the present research only WUR as a mechanical "test stimuli" (TS) was used, but they suggested that adding an additional thermal TS could provide a more comparable CPM. Yarnitsky et al., in 2015, suggested that sequential protocol, i.e., TS performed immediately after "conditioning stimuli" (CS), rather than in parallel, i.e., presentation of the TS at the same time as the CS, provides results free of biases such as distraction. Despite that, we choose to performed parallel protocol since CPM effect is generally short-lived $(29,30)$ and it has been already suggested by Moont et.al. that CPM 
acts independently from distractions (28).

We suspect that a more likely reason for our failure to find an association between CPM and pain outcome relates to the nature of our study sample. Several studies showed an association between the development of chronic pain conditions with ineffective endogenous pain inhibition system tested by CPM (15-18). Based on that we hypothesized that patient's orthodontic pain report could be affected by CPM efficiency. But, the present study failed to find any association. CPM responses have been found to differ in persons with chronic pain when compared to pain-free controls (31). Considering that healthy participants comprised the sample studied, the actual results should be analyzed with caution.

Another technical aspect that deserves to be mentioned relates to cut-off point to divide the data into two groups: CPM responders (G1) and non-responders (G2). Oono et. al. (27) used a $10 \%$ relative difference on TS after CS compared to before. Khan et. al., in 2014 , choose to divide the data into thirds to classify the groups into high, medium, and low exercise hypoalgesia responders based on the percentage of reduction in the number of responses to the TS. There is no gold standard method to perform this analysis, in this way; we choose to follow $10 \%$ relative difference method (27). But, future studies are warranted to address this topic and determined which is the best way to analyze the data

We suspect that a possible CPM efficiency could influence the release of inflammatory mediators, since the incidence of pain may be associated with the interactions of inflammatory mediator (13). The early phase of orthodontic tooth movement involves acute inflammatory responses, which induce the release of several inflammatory mediators to the GCF (5). In addition, it is in the orthodontic early phase that patients report more pain induced, that according to our hypothesized it will be higher in patients CPM responders. But, this association was not observed in the present study.

In conclusion, CPM efficiency may not significantly influence somatosensory function, pain intensity or released of inflammatory cytokines following orthodontic tooth movement up to 1 month after initiated the treatment. However, remained to be confirmed and further investigations are 
required in intraoral somatosensory assessment.

\section{Acknowledgments}

This research was supported by the São Paulo Research Foundation (FAPESP), grants \#2014/18741-0 and \#2015/09913-4 and by the Coordination for the Improvement of Higher Level Personnel (CAPES). There were no conflicts of interest in the performance of this study 


\section{Figure Legend}

Figure 01. Flow chart representing the study design.

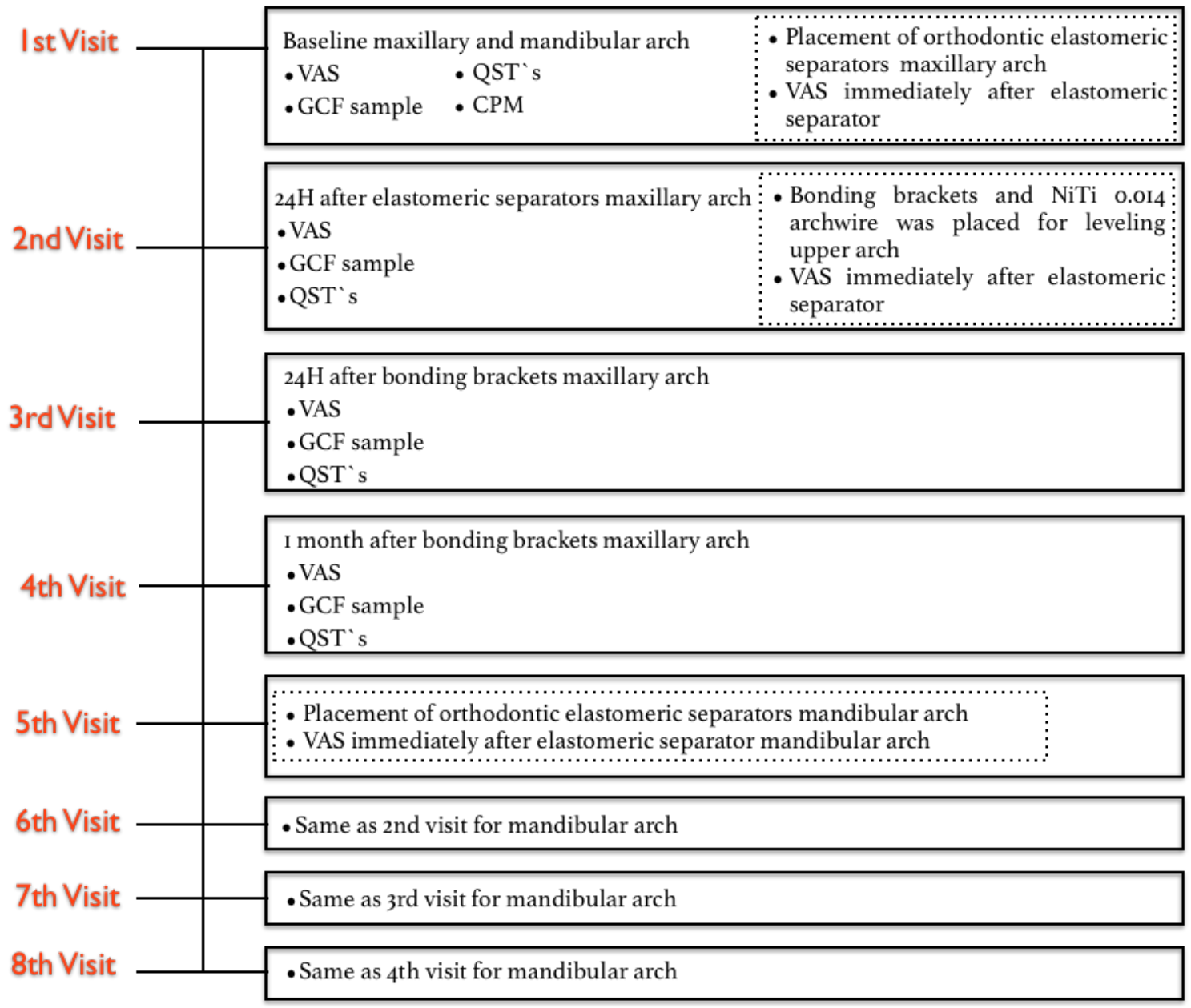




\section{Tables}

Table 01. Comparison between CPM-responder (G1) and CPM non-responder (G2). Mean and standard deviation (s.d.) of the current perception threshold (CPT) test at all time point and sites tested.

* Bold cells present significant $p$-values $(p<0.050)$

\begin{tabular}{|c|c|c|c|c|c|c|c|c|c|c|}
\hline \multirow[b]{3}{*}{ Measurements } & \multicolumn{4}{|c|}{ G1 } & \multicolumn{4}{|c|}{ G2 } & \multicolumn{2}{|c|}{$P$ value } \\
\hline & \multirow{2}{*}{$\begin{array}{c}\text { Infra-orbital n. } \\
\text { Mean }(S D)\end{array}$} & \multicolumn{3}{|c|}{ Mental n. } & \multirow{2}{*}{$\begin{array}{c}\text { Infra-orbital n. } \\
\text { Mean }(S D)\end{array}$} & \multicolumn{3}{|c|}{ Mental n. } & \multirow{2}{*}{ Infra-orbital $n$. } & \multirow{2}{*}{ Mental $n$. } \\
\hline & & $n$ & Mean (SD) & $n$ & & $n$ & Mean (SD) & $n$ & & \\
\hline \multicolumn{11}{|l|}{ CPT } \\
\hline \multicolumn{11}{|l|}{$2000 \mathrm{HZ}$} \\
\hline Baseline & $175.0(81.53)$ & 14 & $120.3(45.2)$ & 14 & $144.3(60.7)$ & 16 & $184.9(180.5)$ & 16 & 0.180 & 0.222 \\
\hline 24h AES & $142.6(83.82)$ & 14 & $155.2(78.5)$ & 13 & $181.1(110.7$ & 16 & $188.5(102.4)$ & 16 & 0.161 & 0.278 \\
\hline $24 \mathrm{~h} \mathrm{AO}$ & $195.7(127.4)$ & 9 & $141.1(61.9)$ & 9 & $184.0(152.5)$ & 11 & $188.5(90.4)$ & 12 & 0.765 & 0.192 \\
\hline 1month $\mathrm{AO}$ & $170.2(74.57)$ & 8 & $192.2(99.1)$ & 9 & $181.4(78.5)$ & 11 & $223.4(122.1)$ & 9 & 0.728 & 0.520 \\
\hline \multicolumn{11}{|l|}{$250 \mathrm{HZ}$} \\
\hline Baseline & $47.3(28.5)$ & 14 & $46.0(17.4)$ & 14 & $29.9(20.1)$ & 16 & $48.0(68.2)$ & 16 & 0.073 & 0.165 \\
\hline 24h AES & $45.0(57.1)$ & 14 & $44.6(26.6)$ & 13 & $47.5(42.8)$ & 16 & $61.1(88.8)$ & 16 & 0.560 & 0.802 \\
\hline $24 \mathrm{~h} \mathrm{AO}$ & 38.6 (38.2) & 9 & $44.8(24.24)$ & 9 & $59.8(78.3)$ & 11 & $66.2(55.0)$ & 12 & 0.341 & 0.766 \\
\hline 1month $A O$ & $28.3(15.1)$ & 8 & $125.7(178.7)$ & 9 & 45.6 (32.2) & 11 & $93.0(87.1)$ & 9 & 0.365 & 0.881 \\
\hline \multicolumn{11}{|l|}{$5 \mathrm{HZ}$} \\
\hline Baseline & 23.4 (22.9) & 14 & $30.1(18.4)$ & 14 & $16.25(12.61)$ & 16 & $19.1(16.0)$ & 16 & 0.144 & 0.029 \\
\hline 24h AES & $30.2(52.4)$ & 14 & $23.3(14.1)$ & 13 & $22.56(25.42)$ & 16 & $30.1(34.0)$ & 16 & 0.612 & 0.800 \\
\hline $24 \mathrm{~h} \mathrm{AO}$ & $17.5(21.3)$ & 9 & $22.2(29.4)$ & 9 & $35.81(38.5)$ & 11 & $36.9(27.3)$ & 12 & 0.093 & 0.282 \\
\hline 1 month $\mathrm{AO}$ & $14.2(9.7)$ & 8 & $74.2(89.9)$ & 9 & $30.1(26.9)$ & 11 & $58.8(63.8)$ & 9 & 0.243 & 0.893 \\
\hline
\end{tabular}

G1 = CPM responder $;$ G2 = CPM non-repsonder

$\mathrm{AES}=$ after elastomeric separator; $\mathrm{AO}=$ after orthodontic bonding $\mathrm{CPT}=$ current perception threshold $(\mathrm{mA})$; 
Table 02. Comparison between CPM-responder (G1) and CPM non-responder (G2). Mean and standard deviation (s.d.) of QST at all time point and sites tested.

$\mathrm{G} 1=\mathrm{CPM}$ responder; $\mathrm{G} 2=\mathrm{CPM}$ non-repsonder; $\mathrm{AES}=$ after elastomeric separator; $\mathrm{AO}=$ after orthodontic bonding; $\mathrm{MDT}=$ mechanical detection threshold $\left(\mathrm{g} / \mathrm{mm}^{2}\right) ; \mathrm{MST}=$ mechanical

\begin{tabular}{|c|c|c|c|c|c|c|c|c|c|c|}
\hline \multirow[b]{3}{*}{ Measurements } & \multicolumn{4}{|c|}{ G1 } & \multicolumn{4}{|c|}{ G2 } & \multicolumn{2}{|c|}{$P$ value } \\
\hline & \multirow{2}{*}{$\frac{\text { Infra-orbital n. }}{\text { Mean (SD) }}$} & \multicolumn{3}{|c|}{ Mental n. } & \multirow{2}{*}{$\begin{array}{c}\text { Infra-orbital n. } \\
\text { Mean (SD) }\end{array}$} & \multicolumn{3}{|c|}{ Mental n. } & \multirow{2}{*}{ Infra-orbital $n$. } & \multirow{2}{*}{ Mental $n$} \\
\hline & & $n$ & Mean (SD) & $n$ & & $n$ & Mean (SD) & $n$ & & \\
\hline \multicolumn{11}{|l|}{ MDT } \\
\hline Baseline & $0.09(0.16)$ & 14 & $0.06(0.15)$ & 14 & $0.17(0.29)$ & 16 & $0.12(0.30)$ & 16 & 0.195 & 0.188 \\
\hline 24h AES & $0.15(0.34)$ & 14 & $0.13(0.24)$ & 13 & $0.15(0.22)$ & 16 & $0.15(0.410$ & 16 & 0.430 & 0.985 \\
\hline $24 \mathrm{~h} \mathrm{AO}$ & $0.13(0.35)$ & 9 & $0.04(0.07)$ & 9 & $0.13(0.26)$ & 11 & $0.12(0.19)$ & 12 & 0.550 & 0.389 \\
\hline 1month $\mathrm{AO}$ & $0.05(0.04)$ & 8 & $0.02(0.02)$ & 9 & $0.15(0.34)$ & 11 & $0.09(0.12)$ & 9 & 0.654 & 0.103 \\
\hline \multicolumn{11}{|l|}{ CDT } \\
\hline Baseline & $28.2(2.4)$ & 14 & 29.1 (2.3) & 14 & $27.9(5.3)$ & 16 & $28.6(5.2)$ & 16 & 0.629 & 0.583 \\
\hline 24h AES & $27.7(4.0)$ & 14 & $28.1(6.1)$ & 13 & $27.9(2.8)$ & 15 & $27.3(4.9)$ & 16 & 0.793 & 0.929 \\
\hline $24 \mathrm{~h} \mathrm{AO}$ & $25.8(6.3)$ & 9 & $27.4(3.5)$ & 9 & $27.3(4.7)$ & 11 & $27.8(3.7)$ & 12 & 0.541 & 0.876 \\
\hline 1 month AO & $25.6(4.2)$ & 8 & $28.9(2.5)$ & 9 & $27.5(3.1)$ & 11 & $28.2(2.5)$ & 9 & 0.281 & 0.595 \\
\hline \multicolumn{11}{|l|}{ HDT } \\
\hline Baseline & $34.8(1.5)$ & 14 & 35.7 (3.2) & 14 & $35.0(3.7)$ & 16 & $65.1(3.8)$ & 16 & 0.902 & 0.855 \\
\hline 24h AES & $35.0(2.1)$ & 14 & $34.9(1.4)$ & 13 & $34.8(1.5)$ & 16 & $35.7(2.7)$ & 16 & 0.794 & 0.422 \\
\hline $24 \mathrm{~h} \mathrm{AO}$ & $35.3(1.2)$ & 9 & $35.2(1.2)$ & 9 & $35.3(2.6)$ & 11 & 36.7 (2.3) & 12 & 0.959 & 0.111 \\
\hline 1month $\mathrm{AO}$ & $35.4(1.6)$ & 8 & $35.6(1.6)$ & 9 & $35.2(1.9)$ & 11 & $36.7(2.1)$ & 9 & 0.830 & 0.261 \\
\hline \multicolumn{11}{|l|}{ MST } \\
\hline Baseline & $2.58(2.8)$ & 14 & $2.83(2.8)$ & 14 & $2.95(2.5)$ & 16 & $2.23(2.5)$ & 16 & 0.234 & 0.222 \\
\hline 24h AES & $2.45(2.9)$ & 14 & $1.39(1.6)$ & 13 & $2.34(2.3)$ & 16 & $2.04(2.2)$ & 16 & 0.936 & 0.293 \\
\hline $24 \mathrm{~h} \mathrm{AO}$ & $2.37(3.1)$ & 9 & $1.56(2.5)$ & 10 & $2.56(2.5)$ & 11 & $2.15(2.5)$ & 12 & 0.870 & 0.251 \\
\hline 1month $\mathrm{AO}$ & $1.40(2.8)$ & 8 & 1.57 (2.2) & 9 & $1.75(1.9)$ & 11 & $2.07(2.6)$ & 9 & 0.189 & 0.464 \\
\hline \multicolumn{11}{|l|}{ WUR } \\
\hline Baseline & $1.77(1.1)$ & 14 & $1.69(0.9)$ & 14 & $1.48(1.3)$ & 16 & $2.96(3.0)$ & 16 & 0.235 & 0.860 \\
\hline 24h AES & $1.85(1.2)$ & 13 & $2.83(1.6)$ & 11 & $1.86(1.2)$ & 16 & $12.74(3.8)$ & 16 & 0.584 & 0.553 \\
\hline $24 \mathrm{~h} \mathrm{AO}$ & $1.72(1.0)$ & 8 & $1.42(0.5)$ & 6 & $1.88(2.3)$ & 11 & $2.45(2.9)$ & 11 & 0.934 & 0.206 \\
\hline 1 month $\mathrm{AO}$ & $2.27(2.7)$ & 5 & $1.19(0.8)$ & 7 & $3.10(3.2)$ & 10 & $3.15(3.5)$ & 8 & 0.307 & 0.110 \\
\hline
\end{tabular}

suprathreshold (pain intensity-VAS); WUR = wind-up ratio (pain intensity-VAS); CDT = cold detection threshold $\left({ }^{\circ} \mathrm{C}\right)$; WDT = warm detection threshold $\left({ }^{\circ} \mathrm{C}\right.$ ). 
Table 03. Comparison between CPM-responder (G1) and CPM non-responder (G2). Mean and standard deviation (s.d.) of pain intensity at all time point and sites tested.

G1 = CPM responder; G2 = CPM non-repsonder;

\begin{tabular}{|c|c|c|c|c|c|c|c|c|c|c|}
\hline \multirow[b]{3}{*}{ Measurements } & \multicolumn{4}{|c|}{ G1 } & \multicolumn{4}{|c|}{ G2 } & \multicolumn{2}{|c|}{$P$ value } \\
\hline & \multirow{2}{*}{$\begin{array}{c}\text { Infra-orbital } \mathrm{n} . \\
\text { Mean (SD) }\end{array}$} & \multicolumn{3}{|c|}{ Mental $\mathrm{n}$. } & \multirow{2}{*}{$\begin{array}{c}\text { Infra-orbital n. } \\
\text { Mean }(S D)\end{array}$} & \multicolumn{3}{|c|}{ Mental n. } & \multirow{2}{*}{ Infra-orbital $n$. } & \multirow{2}{*}{ Mental $n$} \\
\hline & & $n$ & Mean (SD) & $n$ & & $n$ & Mean (SD) & $n$ & & \\
\hline \multicolumn{11}{|l|}{ VAS } \\
\hline Baseline & $0.0(0.0)$ & 14 & $0.0(0.0)$ & 13 & $0.0(0.0)$ & 16 & $0.0(0.0)$ & 16 & - & - \\
\hline Imme AES & $2.0(2.3)$ & 14 & $1.6(2.4)$ & 13 & $2.6(2.9)$ & 16 & $1.6(1.7)$ & 16 & 0.880 & 0.760 \\
\hline $24 \mathrm{~h}$ AES & $1.7(3.0)$ & 14 & $1.2(2.1)$ & 13 & $2.3(2.6)$ & 16 & $1.3(1.7)$ & 16 & 0.477 & 0.614 \\
\hline Imme A0 & $2.1(3.0)$ & 8 & $3.1(4.0)$ & 8 & $1.7(3.3$ & 12 & $2.7(3.1)$ & 12 & 0.661 & 0.749 \\
\hline $24 \mathrm{~h} \mathrm{AO}$ & $4.1(2.7)$ & 10 & $5.0(3.1)$ & 9 & $4.9(2.7)$ & 12 & $3.4(2.9)$ & 12 & 0.351 & 0.301 \\
\hline 1month $\mathrm{AO}$ & $0.0(0.0)$ & 9 & $0.0(0.0)$ & 9 & $0.2(0.5)$ & 12 & $0.4(1.3)$ & 10 & 0.357 & 0.357 \\
\hline
\end{tabular}

$\mathrm{AES}$ = after elastomeric separator; $\mathrm{AO}=$ after orthodontic bonding; Imme AES = immediately after elastomeric separator; Imme $\mathrm{AO}=$ after orthodontic bonding;

VAS $=$ Visual analog scale (pain intensity-VAS) 
Table 04. Comparison between CPM-responder (G1) and CPM non-responder (G2). Mean and standard deviation (s.d.) of the cytokine concentration (pg/ml) at all time point and sites tested.

${ }^{*}$ Bold cells present significant $p$-values $(p<0.050)$

\begin{tabular}{|c|c|c|c|c|c|c|c|c|c|c|}
\hline \multirow[b]{3}{*}{ Measurements } & \multicolumn{4}{|c|}{ G1 } & \multicolumn{4}{|c|}{ G2 } & \multicolumn{2}{|c|}{$P$ value } \\
\hline & \multirow{2}{*}{$\begin{array}{c}\text { Infra-orbital n. } \\
\text { Mean }(S D)\end{array}$} & \multicolumn{3}{|c|}{ Mental $\mathrm{n}$. } & \multirow{2}{*}{$\begin{array}{c}\text { Infra-orbital n. } \\
\text { Mean }(S D)\end{array}$} & \multicolumn{3}{|c|}{ Mental n. } & \multirow{2}{*}{ Infra-orbital $n$. } & \multirow{2}{*}{ Mental $n$} \\
\hline & & $n$ & Mean (SD) & $n$ & & $n$ & Mean (SD) & $n$ & & \\
\hline \multicolumn{11}{|l|}{ IL-1 $\beta$} \\
\hline Baseline & $21.75(7.5)$ & 14 & $22.96(8.1)$ & 13 & $27.93(7.8)$ & 16 & $25.93(6.6)$ & 16 & 0.036 & 0.289 \\
\hline 24h AES & $34.00(5.2)$ & 14 & $32.65(4.9)$ & 13 & $36.71(5.4)$ & 16 & $33.81(5.8)$ & 16 & 0.177 & 0.575 \\
\hline $24 \mathrm{~h} \mathrm{AO}$ & $40.43(6.0)$ & 9 & $42.38(6.6)$ & 9 & $42.38(7.5)$ & 11 & $40.90(6.1)$ & 12 & 0.537 & 0.603 \\
\hline 1month $\mathrm{AO}$ & $53.8(4.9)$ & 8 & $51.30(7.45)$ & 9 & $59.06(11.14)$ & 11 & $55.61(5.6)$ & 9 & 0.235 & 0.187 \\
\hline \multicolumn{11}{|l|}{ IL6 } \\
\hline Baseline & $4.28(1.5)$ & 14 & $5.16(1.6)$ & 13 & $4.65(1.2)$ & 16 & $4.37(1.2)$ & 16 & 0.473 & 0.150 \\
\hline 24h AES & $8.95(3.0)$ & 14 & $10.67(3.7)$ & 13 & $9.59(2.8)$ & 16 & $9.32(2.4)$ & 16 & 0.554 & 0.253 \\
\hline $24 \mathrm{~h} \mathrm{AO}$ & $14.21(2.2)$ & 9 & $17.98(2.7)$ & 9 & $14.23(3.6)$ & 11 & 15.56 (3.3) & 12 & 0.991 & 0.091 \\
\hline 1month AO & $9.32(1.3)$ & 8 & $12.17(1.5)$ & 9 & 11.16 (3.4) & 11 & $10.10(2.0)$ & 9 & 0.167 & 0.027 \\
\hline \multicolumn{11}{|l|}{ IL8 } \\
\hline Baseline & $58.71(6.7)$ & 14 & 58.47 (7.9) & 13 & $57.03(6.3)$ & 16 & $58.14(7.2)$ & 16 & 0.484 & 0.906 \\
\hline 24h AES & $60.78(6.1)$ & 14 & $59.15(7.2)$ & 13 & $59.39(6.0)$ & 16 & $59.37(6.4)$ & 16 & 0.536 & 0.930 \\
\hline $24 \mathrm{~h} A O$ & $58.06(6.8)$ & 9 & $61.45(6.9)$ & 9 & $58.53(5.8)$ & 11 & $57.74(6.4)$ & 12 & 0.869 & 0.223 \\
\hline 1month $\mathrm{AO}$ & $59.37(5.8)$ & 8 & $58.60(6.8)$ & 9 & $57.31(7.45)$ & 11 & $54.70(6.4)$ & 9 & 0.527 & 0.231 \\
\hline \multicolumn{11}{|l|}{ TNF-a } \\
\hline Baseline & $22.83(2.8)$ & 14 & $22.52(5.0)$ & 13 & 20.94 (3.5) & 16 & 21.41 (3.3) & 16 & 0.122 & 0.487 \\
\hline 24h AES & $31.31(5.1)$ & 14 & $31.86(5.45)$ & 13 & 30.25 (4.3) & 16 & $31.46(6.0)$ & 16 & 0.543 & 0.851 \\
\hline $24 \mathrm{~h} \mathrm{AO}$ & $37.79(4.0)$ & 9 & $34.37(5.7)$ & 10 & 34.42 (3.8) & 11 & $33.74(5.0)$ & 12 & 0.072 & 0.795 \\
\hline 1month $\mathrm{AO}$ & $138.66(4.3)$ & 8 & $37.43(7.7)$ & 9 & 37.51 (4.3) & 11 & $37.81(7.3)$ & 9 & 0.576 & 0.916 \\
\hline
\end{tabular}

G1 = CPM responder; G2 = CPM non-repsonder

$\mathrm{AES}=$ after elastomeric separator; $\mathrm{AO}=$ after orthodontic bonding 


\section{References}

1. International Associal for the Study of Pain. 2010.

2. Yarnitsky D. Conditioned pain modulation (the diffuse noxious inhibitory control-like effect): its relevance for acute and chronic pain states. Curr Opin Anaesthesiol. 2010;23(5):611-5.

3. Yarnitsky D, Arendt-Nielsen L, Bouhassira D, Edwards RR, Fillingim RB, Granot M, et al. Recommendations on terminology and practice of psychophysical DNIC testing. European journal of pain (London, England). 2010;14(4):339.

4. Bergius M, Berggren U, Kiliaridis S. Experience of pain during an orthodontic procedure. European journal of oral sciences. 2002;110(2):92-8.

5. Kapoor P, Kharbanda OP, Monga N, Miglani R, Kapila S. Effect of orthodontic forces on cytokine and receptor levels in gingival crevicular fluid: a systematic review. Prog Orthod. 2014;15:65.

6. Grant M, Wilson J, Rock P, Chapple I. Induction of cytokines, MMP9, TIMPs, RANKL and OPG during orthodontic tooth movement. European journal of orthodontics. 2013;35(5):644-51.

7. Ren Y, Vissink A. Cytokines in crevicular fluid and orthodontic tooth movement. European journal of oral sciences. 2008;116(2):89-97.

8. Nicolay OF, Davidovitch Z, Shanfeld JL, Alley K. Substance P immunoreactivity in periodontal tissues during orthodontic tooth movement. Bone Miner. 1990;11(1):19-29.

9. Lv D, Zhang J, Gu X, Shen H, Shao S, Hou W, et al. Transient Pain Following Orthodontic Fixed Appliances Induces Sensitization of Gingival and Periodontal Tissues. J Oral Facial Pain Headache. 2016;30(3):228-33.

10. Shen H, Shao S, Zhang J, Wang Z, Lv D, Chen W, et al. Fixed orthodontic appliances cause pain and disturbance in somatosensory function. European journal of oral sciences. 2016;124(1):26-32.

11. Sood M, Bhatt P, Sessle BJ. Mechanical and thermal hypersensitivities associated with orthodontic tooth movement: a behavioral rat model for orthodontic tooth movement-induced pain. J Oral Facial Pain Headache. 2015;29(1):60-9.

12. Grieve WG, 3rd, Johnson GK, Moore RN, Reinhardt RA, DuBois LM. Prostaglandin E (PGE) and interleukin-1 beta (IL-1 beta) levels in gingival crevicular fluid during human orthodontic tooth movement. American journal of orthodontics and dentofacial orthopedics : official publication of the American Association of Orthodontists, its constituent societies, and the American Board of Orthodontics. 1994;105(4):369-74.

13. Giannopoulou C, Dudic A, Kiliaridis S. Pain discomfort and crevicular fluid changes induced by orthodontic elastic separators in children. The journal of pain : official journal of the American Pain Society. 2006;7(5):367-76.

14. Yarnitsky D, Crispel Y, Eisenberg E, Granovsky Y, Ben-Nun A, Sprecher E, et al. Prediction of chronic post-operative pain: pre-operative DNIC testing identifies patients at risk. Pain. 2008;138(1):22-8.

15. King CD, Wong F, Currie T, Mauderli AP, Fillingim RB, Riley JL, 3rd. Deficiency in endogenous modulation of prolonged heat pain in patients with Irritable Bowel Syndrome and Temporomandibular Disorder. Pain. 2009;143(3):172-8.

16. Maixner W, Fillingim R, Sigurdsson A, Kincaid S, Silva S. Sensitivity of patients with painful temporomandibular disorders to experimentally evoked pain: evidence for altered temporal summation of pain. Pain. 1998;76(1-2):71-81.

17. Julien N, Goffaux P, Arsenault P, Marchand S. Widespread pain in fibromyalgia is related to a deficit of endogenous pain inhibition. Pain. 2005;114(1-2):295-302. 
18. Pielsticker A, Haag G, Zaudig M, Lautenbacher S. Impairment of pain inhibition in chronic tension-type headache. Pain. 2005;118(1-2):215-23.

19. Yarnitsky D, Bouhassira D, Drewes AM, Fillingim RB, Granot M, Hansson P, et al. Recommendations on practice of conditioned pain modulation (CPM) testing. European journal of pain (London, England). 2015;19(6):805-6.

20. Rolke R, Magerl W, Campbell KA, Schalber C, Caspari S, Birklein F, et al. Quantitative sensory testing: a comprehensive protocol for clinical trials. European journal of pain (London, England). 2006;10(1):77-88.

21. Ziccardi VB, Dragoo J, Eliav E, Benoliel R. Comparison of current perception threshold electrical testing to clinical sensory testing for lingual nerve injuries. J Oral Maxillofac Surg. 2012;70(2):289-94.

22. Porporatti AL, Bonjardim LR, Stuginski-Barbosa J, Bonfante EA, Costa YM, Rodrigues Conti PC. Pain from Dental Implant Placement, Inflammatory Pulpitis Pain, and Neuropathic Pain Present Different Somatosensory Profiles. J Oral Facial Pain Headache. 2017;31(1):1929.

23. Costa YM, Morita-Neto O, de Araujo-Junior EN, Sampaio FA, Conti PC, Bonjardim LR. Test-retest reliability of quantitative sensory testing for mechanical somatosensory and pain modulation assessment of masticatory structures. Journal of oral rehabilitation. 2017;44(3):197-204.

24. Lamster IB, Hartley LJ, Oshrain RL, Gordon JM. Evaluation and modification of spectrophotometric procedures for analysis of lactate dehydrogenase, beta-glucuronidase and arylsulphatase in human gingival crevicular fluid collected with filter-paper strips. Archives of oral biology. 1985;30(3):235-42.

25. de Oliveira RR, Schwartz-Filho HO, Novaes AB, Garlet GP, de Souza RF, Taba M, et al. Antimicrobial photodynamic therapy in the non-surgical treatment of aggressive periodontitis: cytokine profile in gingival crevicular fluid, preliminary results. Journal of periodontology. 2009;80(1):98-105.

26. Garlet GP, Cardoso CR, Silva TA, Ferreira BR, Avila-Campos MJ, Cunha FQ, et al. Cytokine pattern determines the progression of experimental periodontal disease induced by Actinobacillus actinomycetemcomitans through the modulation of MMPs, RANKL, and their physiological inhibitors. Oral Microbiol Immunol. 2006;21(1):12-20.

27. Oono Y, Wang K, Svensson P, Arendt-Nielsen L. Conditioned pain modulation evoked by different intensities of mechanical stimuli applied to the craniofacial region in healthy men and women. J Orofac Pain. 2011;25(4):364-75.

28. Moont R, Pud D, Sprecher E, Sharvit G, Yarnitsky D. 'Pain inhibits pain' mechanisms: Is pain modulation simply due to distraction? Pain. 2010;150(1):113-20.

29. Kakigi R. Diffuse noxious inhibitory control. Reappraisal by pain-related somatosensory evoked potentials following CO2 laser stimulation. J Neurol Sci. 1994;125(2):198-205.

30. Sandrini G, Serrao M, Rossi P, Romaniello A, Cruccu G, Willer JC. The lower limb flexion reflex in humans. Prog Neurobiol. 2005;77(6):353-95.

31. LeResche L, Turner JA, Saunders K, Shortreed SM, Von Korff M. Psychophysical tests as predictors of back pain chronicity in primary care. The journal of pain : official journal of the American Pain Society. 2013;14(12):1663-70. 


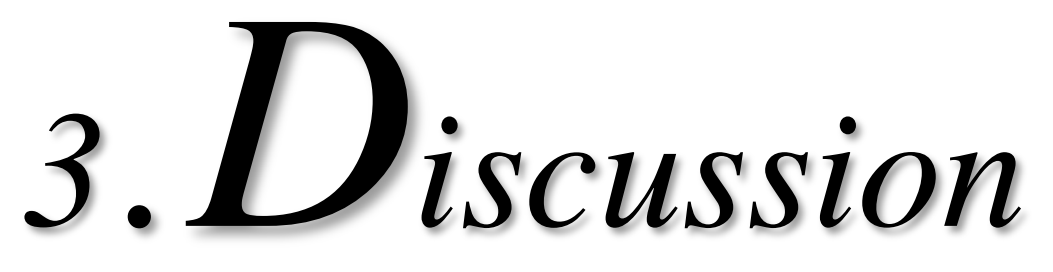





\section{DISCUSSION}

To our knowledge, the present study is the first to evaluate a possible association of inflammatory mediator, pain, pain modulation and somatosensory function following orthodontic procedures. The results showed that patients reported more pain $24 \mathrm{~h}$-after fixed orthodontic appliance when compared to baseline. The orthodontic treatment was associated with less sensitivity to a pin-prick stimulation $24 \mathrm{~h}$ and 1 month-after fixed appliance bonding, but no changes were found in MDT or thermal detection thresholds. There was a trend of increase in IL-1 $\beta$, IL-6 and TNF- $\alpha$ levels $24 \mathrm{~h}$-after elastic separator but no significant difference was found when compared to baseline values. The IL-6 levels were significantly increased $24 \mathrm{~h}$-after bonding the orthodontic. However, the IL-1 $\beta$ and TNF- $\alpha$ were significantly higher only 1 month after treatment onset when compared to baseline. Moreover, the results of this study did not support the hypothesis that CPM efficiency impacts pain intensity, somatosensory function and release of inflammatory cytokines following orthodontic tooth movement at any time point tested in this study. After the correction for multiple comparisons, no significant correlations were found.

Pain is defined by the International Association for the Study of Pain (IASP) as "an unpleasant sensory and emotional experience associated with actual or potential tissue damage, or described in terms of such damage" (2). Pain is always subjective. Orthodontic pain is one of the most unpleasant reactions to orthodontic therapy, and sometimes can lead to patient's treatment discontinue. Usually, patients report more pain following elastic separator or as soon as fixed orthodontic appliance is placed. In the present study we decided to examine both methods of stimulating orthodontic tooth movement. Lv et al. in 2016 reported that patients complaint of moderate orthodontic pain induced that peaks $24 \mathrm{~h}$-after orthodontic force are applied (mean VAS $=4.2 \pm 1.8 \mathrm{~cm}$ ) (39). Those results are similar to the one reported in the present study, where patients reported moderate pain intensity $24 \mathrm{~h}$-after bonding the fixed orthodontic appliance (mean VAS $=4.59 \pm 2.69(\mathrm{~V} 2)$ and $4.14 \pm 3.02(\mathrm{~V} 3)$ ) but only mild pain intensity following elastic separator (mean VAS $=2.0 \pm 2.80$ (V2) and $1.31 \pm 1.88(\mathrm{~V} 3))$, which were expected. We could pointed two possible explanation for this difference in pain report when compared those different methods to induce OTM: 1) The fixed orthodontic appliance stimulate all teeth at the same time and elastic separator only stimulate two contiguous teeth; 2) high levels of inflammation in the periodontal ligament between $12 \mathrm{~h}$ and $36 \mathrm{~h}$ after bonding $(18,19,32)$, which were confirmed by the present study. 
No significant difference was observed after elastic separator, but there was an increase in pro-inflammatory mediators $24 \mathrm{~h}$ and 1 month after bonding.

It is well establish how OTM induces local inflammation and pain, but the individual response it is not predictable. Various authors have studied orthodontic pain and the different factors that modify it, which included gender, personality, and previous experience of pain in dental treatment (42). But, to our knowledge this is the first study to evaluate a possible individual endogenous analgesia effect on orthodontic induced-pain.

Endogenous analgesia (EA) is a mechanism that can control or reduce pain. The term Conditioned Pain Modulation (CPM) is used to describe psychophysical paradigm designed to assess the EA (pain reducing pain). This mechanism is assessing by applying two remote noxious stimuli which one inhibits the other (8). Several studies showed an association between the developments of chronic pain conditions with inefficient endogenous pain inhibition system tested by CPM (10-13). Based on that, we hypothesized that patient's orthodontic pain perception could be affected by CPM efficiency. This hypothesis was rejected.

We suspect that a possible CPM efficiency could influence the release of inflammatory mediators, since the incidence of pain may be associated with the interactions of inflammatory mediator (17). The early phase of orthodontic tooth movement involves acute inflammatory responses, which induce the release of several inflammatory mediators to the GCF (18). In addition, it is in the orthodontic early phase that patients report more pain induced, that according to our hypothesized it will be higher in patients CPM responders. But, this association was not observed in the present study.

The lack of any significant association between CPM efficiency and the outcome variables of the present study was an interesting finding. CPM efficiency may help to identify patients "at risk" for the development of chronic pain (9), but failed to predict patients "at risk" to perceive more pain following OTM. CPM responses have been found to differ in persons with chronic pain when compared to pain-free controls (43). Considering that healthy participants comprised the sample studied, the actual results should be analyzed with caution. Moreover, even though the methods used in the present research was similar to many in common use $(36,44-46)$, it differ in some aspects from the protocol suggested by some CPM researchers-expert published by Yarnitsky et al., in 2015. It is possible that the specific parameters of our CPM testing contributed to the lack of association.

In the present research we performed only WUR as a mechanical "test stimuli" (TS), 
but they suggested adding an additional thermal TS could provide a more comparable CPM. Unfortunately, due to the magnitude of the study, 8 sessions, each session taking around 60 minutes, we did not have enough time to perform different "test stimuli" methods. In face of that we opted to perform a mechanical test following other authors protocol $(36,46)$. Besides, Yarnitsky et al., in 2015, suggested that sequential protocol, i.e., TS performed immediately after "conditioning stimuli" (CS), rather than in parallel, i.e., presentation of the TS at the same time as the CS, provides a result free of biases such as distraction. Despite that, we choose to performed parallel protocol since CPM effect is generally short-lived $(47,48)$ and it has been already suggested by Moont et.al. (44) that CPM is an effective method reducing perceived pain and has a different physiological mechanism underlie distraction and CPM.

A review on neural mechanisms of nociception during orthodontic treatment published in 2017 by Kobayashi et al. (32) suggested that the release of IL-1 $\beta$ and TNF- $\alpha$ mediate inflammatory hyperalgesia by generating the release of prostaglandins (PGs), which sensitize nociceptors on C-fibers. Even though the present study show an increase in those two proinflammatory cytokines 1 month after initiate orthodontic force we could not find any hyperalgesia in the infra-orbital or mental nerves territory. This may be due to a site-specific effect discussed above. Moreover, there is no elevation on systemic cytokine-mediator following conventional orthodontic treatment (49), which may explain a site-specific effect. The results of the present study may suggest that orthodontic-induced inflammation, at least at the GCF, is insufficient to evoke significant change in mechanical and thermal threshold at extra-oral nerve territory.

The early phase of orthodontic tooth movement involves acute inflammatory responses, which induce several inflammatory mediators to be released into the gingival crevicular fluid. GCF analysis has been proven to be an effective method to identify specific biomarkers with reasonable sensitivity, therefore, an important tool to study PDL and alveolar bone remodeling $(18,50)$. Majeed et al., in 2016, (51) performed a systematic review on identification of GCF sampling. They concluded that paper strips are the most convenient and accurate method for GCF collection, while enzyme-linked immunosorbent assay can be considered the most conventional method for the diagnosis of biofluids. Perinetti et al. in 2013 (52), reported that measurement of GCF volume it is not a reliable outcome for tissue remodeling incident to OTM. Moreover, the cytokine local concentration seems to be more important than the total amount of cytokine present (20).

It has been shown in previous studies that the most commonly studied cytokines in 
association with orthodontic treatment are IL-1 $\beta$, IL-6, IL-8 and TNF- $\alpha(18,20)$, therefore those are the cytokines chosen to be evaluated in the present study. Apparently, there was a trend of IL-6, IL-1 $\beta$ and TNF- $\alpha$ increase $24 \mathrm{~h}$-after separator, however not significant when compared to baseline values. The orthodontic appliance, on the other hand, induced a significant increase in IL-6 levels after $24 \mathrm{~h}$ and in IL- $1 \beta$ and TNF- $\alpha$ levels after a month. Manifold studies have showed increase in IL-1 $\beta$ as early as $1 \mathrm{~min}$ to $1 \mathrm{~h}$ reaching peak at $24 \mathrm{~h}$ (17-20, 53). But, Kappor et al., (18) reported, in a systematic review, studies showing a peak of IL-1 $\beta$ up to 6 months. In the present study, IL-1 $\beta$ levels peak one month after leveling. It is also imported to notice that light continuous force $(54,55)$ tended to maintain relatively high IL-1 $\beta$ levels for a longer period (20), which might explain why IL-1 $\beta$ levels show a tend to increase $24 \mathrm{~h}$-after separator but only peaks after 1-month of continuous orthodontic force applied. Treatment mechanisms might be an important factor in the secretion regulation of those mediators and different cytokines may respond different to similar mechanisms (20).

Moreover, inflammation along the nerve trunk (perineural inflammation) can cause neuritis. Eliav et al. reported significantly increased IL-6 and IL- $1 \beta$ secretion by perineural inflammation induced in rats. The IL-6 was more prominent immediately following application when the pain peaked and reduced as the pain resolved. IL-1 $\beta$ activity remained elevated in a later stage after the resolution of the pain. This study might therefore support our finding of increased IL-6 in early stage and IL-1 $\beta$ in a later stage.

Although QST has been proven of high value in various orofacial pathologies, to our knowledge, only two studies $(39,40)$ applied it to patients undergoing orthodontic treatment and one study was conducted on a rat model (41). The study performed by Sood et al., 2015, shown a bilateral mechanical and thermal hypersensitivities following orthodontic tooth movement (OTM) model in rats, with peaks reached on postoperative day-1. However, the authors suggested that those somatosensory alterations could be results of a hyperocclusionbased hypersensitivity. Since the heavy intensity of the initial force used in this OTM rat model may lead to an immediate forced eruption of the tooth and thereby cause hyperocclusion and therefore not simulating the clinical condition in humans (41). The previous two clinical studies reported some site-specific somatosensory alteration. Lv et al. reported an alteration to pressure threshold in the attached gingiva and in the periodontal ligament $24 \mathrm{~h}$-following orthodontic appliance placement. Shen et al. found a hypersensitive to cold and hyposensitive to pressure at the site of the tooth movement up to 1 month after orthodontic force was applied. Both studies found some somatosensory alteration intra-orally, either at gingival site or directly to the crowns of the teeth, which diverge from the present 
study that the tests were performed extra-orally.

In the present study, the orthodontic fixed appliance was associated with decreased sensitivity (less pain) to pin-prick pain $24 \mathrm{~h}$ and 1 month after beginning the treatment. Moreover, patient experienced more pain intensity $24 \mathrm{~h}$-after orthodontic fixed appliance, suggesting that maybe an EA effect is present, since two different noxious stimuli were applied (orthodontic force and pin-prick test). However, patients were not experience pain 1 month following orthodontic treatment and they still report a hyposensitive to pin-prick stimuli. The exact mechanism underlying those results remain unknown but could be related to elevated levels of pro-inflammatory-cytokine at this time point.

Larrea et al. (42) reported that females felt more pain than male when pain reached its peak, but also resolve faster. Some studies suggested that estrous cycle might have an effect on mediator levels (18). However, gender effect could not be studied due to the limited study sample. In this way, a larger sample size would allow to address this analysis.

Pain varies at different stages of orthodontic treatment, so the present study focused on pain experienced in the initial stage in order to eliminate a possible bias. Nevertheless, 1 month is a short effect compared to the long orthodontic time course; so, future longer-lasting studies should be performed to a better understanding of possible somatosensory changes along the whole orthodontic treatment. Additionally, it would be interesting to study the cytokines effect on intraoral-somatosensory profile.

Another technical aspect that deserves to be mentioned is regardless the control group. Unfortunately, there is no normative parameter to analyze QST results; in this way the comparison between the non-affected contra-lateral site (38) or before intervention is suggested (20). Therefore, in the present study since all the teeth it was under orthodontic pressure it seems practical to use the baseline levels at experimental teeth as controls (20).

On top of that, with regard to the cut-off point to divide the data into two groups: CPM responders (G1) and non-responders (G2). Oono et al. (56) used a 10\% relative difference on TS after CS compared to before. Khan et. al., in 2014, choose to divide the data into thirds to classify the groups into high, medium, and low exercise hypoalgesia responders based on the percentage of reduction in the number of responses to the TS. There is no gold standard method to perform this analysis, in this way; we choose to follow $10 \%$ relative difference method (56). But, future studies are warranted to address this topic and determined which is the best way to analyze the data. 
Discussion 65 


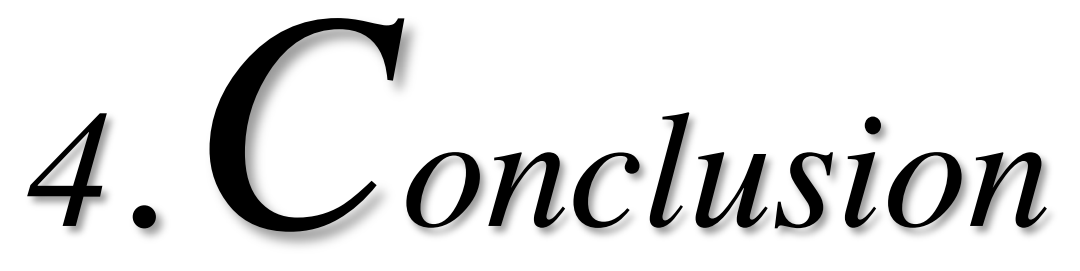





\section{CONCLUSIONS}

In conclusion, orthodontic-induced inflammation may have a modality specific effect on somatosensory function of the trigeminal system, since we could not find significant differences in detection thresholds but only for pain sensitivity. In addition, elastic separators seems not an ideal model to study possible inflammatory changes following orthodontic tooth movement, since it only could induce mild pain and was not able to increase significantly proinflammatory cytokines level. Moreover, CPM efficiency may not significantly influence somatosensory function, pain intensity or released of inflammatory cytokines following orthodontic tooth movement up to 1 month after initiated the treatment. However, remained to be confirmed and further investigations are required in intraoral somatosensory assessment 
References 



\section{REFERECENCES}

1. Brezniak N, Wasserstein A. Orthodontically induced inflammatory root resorption. Part I: The basic science aspects. The Angle orthodontist. 2002;72(2):175-9.

2. International Associal for the Study of Pain. 2010.

3. Scheurer PA, Firestone AR, Burgin WB. Perception of pain as a result of orthodontic treatment with fixed appliances. European journal of orthodontics. 1996;18(4):349-57.

4. Ngan P, Kess B, Wilson S. Perception of discomfort by patients undergoing orthodontic treatment. American journal of orthodontics and dentofacial orthopedics : official publication of the American Association of Orthodontists, its constituent societies, and the American Board of Orthodontics. 1989;96(1):47-53.

5. Leavitt AH, King GJ, Ramsay DS, Jackson DL. A longitudinal evaluation of pulpal pain during orthodontic tooth movement. Orthodontics \& craniofacial research. 2002;5(1):29-37.

6. Bergius M, Berggren U, Kiliaridis S. Experience of pain during an orthodontic procedure. European journal of oral sciences. 2002;110(2):92-8.

7. Yarnitsky D. Conditioned pain modulation (the diffuse noxious inhibitory control-like effect): its relevance for acute and chronic pain states. Curr Opin Anaesthesiol. 2010;23(5):611-5.

8. Yarnitsky D, Arendt-Nielsen L, Bouhassira D, Edwards RR, Fillingim RB, Granot M, et al. Recommendations on terminology and practice of psychophysical DNIC testing. European journal of pain (London, England). 2010;14(4):339.

9. Yarnitsky D, Crispel Y, Eisenberg E, Granovsky Y, Ben-Nun A, Sprecher E, et al. Prediction of chronic post-operative pain: pre-operative DNIC testing identifies patients at risk. Pain. 2008;138(1):22-8.

10. King CD, Wong F, Currie T, Mauderli AP, Fillingim RB, Riley JL, 3rd. Deficiency in endogenous modulation of prolonged heat pain in patients with Irritable Bowel Syndrome and Temporomandibular Disorder. Pain. 2009;143(3):172-8.

11. Maixner W, Fillingim R, Sigurdsson A, Kincaid S, Silva S. Sensitivity of patients with painful temporomandibular disorders to experimentally evoked pain: evidence for altered temporal summation of pain. Pain. 1998;76(1-2):71-81. 
12. Julien N, Goffaux P, Arsenault P, Marchand S. Widespread pain in fibromyalgia is related to a deficit of endogenous pain inhibition. Pain. 2005;114(1-2):295-302.

13. Pielsticker A, Haag G, Zaudig M, Lautenbacher S. Impairment of pain inhibition in chronic tension-type headache. Pain. 2005;118(1-2):215-23.

14. Yarnitsky D, Bouhassira D, Drewes AM, Fillingim RB, Granot M, Hansson P, et al. Recommendations on practice of conditioned pain modulation (CPM) testing. European journal of pain (London, England). 2015;19(6):805-6.

15. Nicolay OF, Davidovitch Z, Shanfeld JL, Alley K. Substance P immunoreactivity in periodontal tissues during orthodontic tooth movement. Bone Miner. 1990;11(1):19-29.

16. Grieve WG, 3rd, Johnson GK, Moore RN, Reinhardt RA, DuBois LM. Prostaglandin E (PGE) and interleukin-1 beta (IL-1 beta) levels in gingival crevicular fluid during human orthodontic tooth movement. American journal of orthodontics and dentofacial orthopedics : official publication of the American Association of Orthodontists, its constituent societies, and the American Board of Orthodontics. 1994;105(4):369-74.

17. Giannopoulou C, Dudic A, Kiliaridis S. Pain discomfort and crevicular fluid changes induced by orthodontic elastic separators in children. The journal of pain : official journal of the American Pain Society. 2006;7(5):367-76.

18. Kapoor P, Kharbanda OP, Monga N, Miglani R, Kapila S. Effect of orthodontic forces on cytokine and receptor levels in gingival crevicular fluid: a systematic review. Prog Orthod. 2014;15:65.

19. Grant M, Wilson J, Rock P, Chapple I. Induction of cytokines, MMP9, TIMPs, RANKL and OPG during orthodontic tooth movement. European journal of orthodontics. 2013;35(5):644-51.

20. Ren Y, Vissink A. Cytokines in crevicular fluid and orthodontic tooth movement. European journal of oral sciences. 2008;116(2):89-97.

21. Yamaguchi M, Kasai K. Inflammation in periodontal tissues in response to mechanical forces. Arch Immunol Ther Exp (Warsz). 2005;53(5):388-98.

22. Dudic A, Kiliaridis S, Mombelli A, Giannopoulou C. Composition changes in gingival crevicular fluid during orthodontic tooth movement: comparisons between tension and compression sides. European journal of oral sciences. 2006;114(5):416-22. 
23. Eliav E, Benoliel R, Herzberg U, Kalladka M, Tal M. The role of IL-6 and IL-1beta in painful perineural inflammatory neuritis. Brain Behav Immun. 2009;23(4):474-84.

24. Irwin CR, Myrillas TT. The role of IL-6 in the pathogenesis of periodontal disease. Oral Dis. 1998;4(1):43-7.

25. Yakovlev E, Kalichman I, Pisanti S, Shoshan S, Barak V. Levels of cytokines and collagen type I and type III as a function of age in human gingivitis. Journal of periodontology. 1996;67(8):788-93.

26. Okada N, Kobayashi M, Mugikura K, Okamatsu Y, Hanazawa S, Kitano S, et al. Interleukin-6 production in human fibroblasts derived from periodontal tissues is differentially regulated by cytokines and a glucocorticoid. Journal of periodontal research. 1997;32(7):559-69.

27. Shimizu N, Ogura N, Yamaguchi M, Goseki T, Shibata Y, Abiko Y, et al. Stimulation by interleukin-1 of interleukin-6 production by human periodontal ligament cells. Archives of oral biology. 1992;37(9):743-8.

28. Stashenko P, Obernesser MS, Dewhirst FE. Effect of immune cytokines on bone. Immunol Invest. 1989;18(1-4):239-49.

29. Dinarello CA. Interleukin-1 and its biologically related cytokines. Adv Immunol. 1989;44:153-205.

30. Ren Y, Maltha JC, Van't Hof MA, Von Den Hoff JW, Kuijpers-Jagtman AM, Zhang D. Cytokine levels in crevicular fluid are less responsive to orthodontic force in adults than in juveniles. Journal of clinical periodontology. 2002;29(8):757-62.

31. Iwasaki LR, Gibson CS, Crouch LD, Marx DB, Pandey JP, Nickel JC. Speed of tooth movement is related to stress and IL-1 gene polymorphisms. American journal of orthodontics and dentofacial orthopedics : official publication of the American Association of Orthodontists, its constituent societies, and the American Board of Orthodontics. 2006;130(6):698 e1-9.

32. Kobayashi M, Horinuki E. Neural mechanisms of nociception during orthodontic treatment. J Oral Sci. 2017;59(2):167-71.

33. Eliav E, Gracely RH, Nahlieli O, Benoliel R. Quantitative sensory testing in trigeminal nerve damage assessment. J Orofac Pain. 2004;18(4):339-44. 
34. Eliav E, Teich S, Benoliel R, Nahlieli O, Lewkowicz AA, Baruchin A, et al. Large myelinated nerve fiber hypersensitivity in oral malignancy. Oral Surg Oral Med Oral Pathol Oral Radiol Endod. 2002;94(1):45-50.

35. Nasri-Heir C, Gomes J, Heir GM, Ananthan S, Benoliel R, Teich S, et al. The role of sensory input of the chorda tympani nerve and the number of fungiform papillae in burning mouth syndrome. Oral Surg Oral Med Oral Pathol Oral Radiol Endod. 2011;112(1):65-72.

36. Rolke R, Magerl W, Campbell KA, Schalber C, Caspari S, Birklein F, et al. Quantitative sensory testing: a comprehensive protocol for clinical trials. European journal of pain (London, England). 2006;10(1):77-88.

37. Sang CN, Max MB, Gracely RH. Stability and reliability of detection thresholds for human A-Beta and A-delta sensory afferents determined by cutaneous electrical stimulation. J Pain Symptom Manage. 2003;25(1):64-73.

38. Kemler MA, Schouten HJ, Gracely RH. Diagnosing sensory abnormalities with either normal values or values from contralateral skin: comparison of two approaches in complex regional pain syndrome I. Anesthesiology. 2000;93(3):718-27.

39. Lv D, Zhang J, Gu X, Shen H, Shao S, Hou W, et al. Transient Pain Following Orthodontic Fixed Appliances Induces Sensitization of Gingival and Periodontal Tissues. J Oral Facial Pain Headache. 2016;30(3):228-33.

40. Shen H, Shao S, Zhang J, Wang Z, Lv D, Chen W, et al. Fixed orthodontic appliances cause pain and disturbance in somatosensory function. European journal of oral sciences. 2016;124(1):26-32.

41. Sood M, Bhatt P, Sessle BJ. Mechanical and thermal hypersensitivities associated with orthodontic tooth movement: a behavioral rat model for orthodontic tooth movementinduced pain. J Oral Facial Pain Headache. 2015;29(1):60-9.

42. Larrea M, Salvador R, Cibrian R, Gandia JL, Paredes-Gallardo V. A New Equation for Predicting Evolution of Oral Pain in Orthodontic Treatment: A Longitudinal, Prospective Cohort Study. J Oral Facial Pain Headache. 2017;31(2):172-9.

43. LeResche L, Turner JA, Saunders K, Shortreed SM, Von Korff M. Psychophysical tests as predictors of back pain chronicity in primary care. The journal of pain : official journal of the American Pain Society. 2013;14(12):1663-70.

44. Moont R, Pud D, Sprecher E, Sharvit G, Yarnitsky D. 'Pain inhibits pain' mechanisms: Is pain modulation simply due to distraction? Pain. 2010;150(1):113-20. 
45. Costa YM, Morita-Neto O, de Araujo-Junior EN, Sampaio FA, Conti PC, Bonjardim LR. Test-retest reliability of quantitative sensory testing for mechanical somatosensory and pain modulation assessment of masticatory structures. Journal of oral rehabilitation. 2017;44(3):197-204.

46. Porporatti AL, Bonjardim LR, Stuginski-Barbosa J, Bonfante EA, Costa YM, Rodrigues Conti PC. Pain from Dental Implant Placement, Inflammatory Pulpitis Pain, and Neuropathic Pain Present Different Somatosensory Profiles. J Oral Facial Pain Headache. 2017;31(1):19-29.

47. Kakigi R. Diffuse noxious inhibitory control. Reappraisal by pain-related somatosensory evoked potentials following $\mathrm{CO} 2$ laser stimulation. J Neurol Sci. 1994;125(2):198-205.

48. Sandrini G, Serrao M, Rossi P, Romaniello A, Cruccu G, Willer JC. The lower limb flexion reflex in humans. Prog Neurobiol. 2005;77(6):353-95.

49. MacLaine JK, Rabie AB, Wong R. Does orthodontic tooth movement cause an elevation in systemic inflammatory markers? European journal of orthodontics. 2010;32(4):435-40.

50. Insoft M, King GJ, Keeling SD. The measurement of acid and alkaline phosphatase in gingival crevicular fluid during orthodontic tooth movement. American journal of orthodontics and dentofacial orthopedics : official publication of the American Association of Orthodontists, its constituent societies, and the American Board of Orthodontics. 1996;109(3):287-96.

51. Nazar Majeed Z, Philip K, Alabsi AM, Pushparajan S, Swaminathan D. Identification of Gingival Crevicular Fluid Sampling, Analytical Methods, and Oral Biomarkers for the Diagnosis and Monitoring of Periodontal Diseases: A Systematic Review. Dis Markers. 2016;2016:1804727.

52. Perinetti G, Primozic J, Castaldo A, Di Lenarda R, Contardo L. Is gingival crevicular fluid volume sensitive to orthodontic tooth movement? A systematic review of splitmouth longitudinal studies. Orthodontics \& craniofacial research. 2013;16(1):1-19.

53. Yamaguchi M, Yoshii M, Kasai K. Relationship between substance P and interleukin1beta in gingival crevicular fluid during orthodontic tooth movement in adults. European journal of orthodontics. 2006;28(3):241-6.

54. Iwasaki LR, Crouch LD, Tutor A, Gibson S, Hukmani N, Marx DB, et al. Tooth movement and cytokines in gingival crevicular fluid and whole blood in growing and adult subjects. American journal of orthodontics and dentofacial orthopedics : official 
publication of the American Association of Orthodontists, its constituent societies, and the American Board of Orthodontics. 2005;128(4):483-91.

55. Lee KJ, Park YC, Yu HS, Choi SH, Yoo YJ. Effects of continuous and interrupted orthodontic force on interleukin-1beta and prostaglandin E2 production in gingival crevicular fluid. American journal of orthodontics and dentofacial orthopedics : official publication of the American Association of Orthodontists, its constituent societies, and the American Board of Orthodontics. 2004;125(2):168-77.

56. Oono Y, Wang K, Svensson P, Arendt-Nielsen L. Conditioned pain modulation evoked by different intensities of mechanical stimuli applied to the craniofacial region in healthy men and women. J Orofac Pain. 2011;25(4):364-75. 